\title{
DEPARTMENT OF ENERGY STANDARD FOR THE PERFORMANCE TESTING OF PERSONNEL DOSIMETRY SYSTEMS
}

\author{
DOE Laboratory Accreditation Program \\ for Personnel Dosimetry Systems
}

Published December 1986

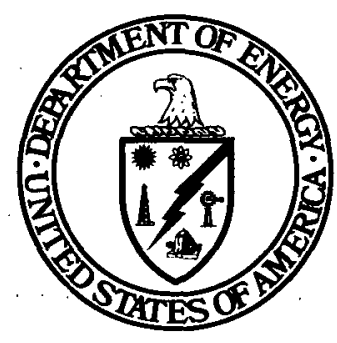

U.S. Department of Energy

Assistant Secretary for Environment, Safety, and Health

Washington, D.C. 20545 


\section{DISCLAIMER}

This report was prepared as an account of work sponsored by an agency of the United States Government. Neither the United States Government nor any agency Thereof, nor any of their employees, makes any warranty, express or implied, or assumes any legal liability or responsibility for the accuracy, completeness, or usefulness of any information, apparatus, product, or process disclosed, or represents that its use would not infringe privately owned rights. Reference herein to any specific commercial product, process, or service by trade name, trademark, manufacturer, or otherwise does not necessarily constitute or imply its endorsement, recommendation, or favoring by the United States Government or any agency thereof. The views and opinions of authors expressed herein do not necessarily state or reflect those of the United States Government or any agency thereof. 


\section{DISCLAIMER}

Portions of this document may be illegible in electronic image products. Images are produced from the best available original document. 


\section{FOREWORD}

This standard is intended to be used in the Department of Energy Laboratory Accreditation Program (DOELAP) for personnel dosimetry systems. It is based on the American National Standards Institute's (ANSI) Criteria for Testing Personnel Dosimetry Performance, ANSI N13.11-1983, ${ }^{1}$ recommendations made to DOE in Guidelines for the Calibration of Personnel Dosimeters, Pacific Northwest Laboratory (PNL) $-4515^{2}$ and comments received during peer review by DOE and DOE contractor personnel. The recommendations contained in PNL-4515 were based on an evaluation of ANSI N13.11 conducted for the Office of Nuclear Safety, DOE, by PNL. ${ }^{3}$ Parts of ANSI N13.11 that did not require modification were used essentially intact in this standard to maintain consistency with nationally recognized standards.

Modifications to this standard have resulted from several DOE/DOE contractor reviews and a pilot testing session. An initial peer review by selected DOE and DOE contractor representatives on technical content was conducted in 1983. A review by DOE field offices, program offices, and contractors was conducted in mid-1984. A pilot performance testing session sponsored by the Office of Nuclear Safety was conducted in early 1985 by the Radiological and Environmental Sciences Laboratory, Idaho Falls. ${ }^{4}$ Results of the pilot test were reviewed in late 1985 by a DOE and DOE contractor committee.

The DOE Laboratory Accreditation Program provides a structured means for assuring the quality of personnel dosimetry performance. The program was initiated and developed by the DOE Office of Nuclear Safety (Environment, Safety and Health) to improve the quality of personnel dosimetry through (1) performance testing, (2) dosimetry and calibration intercomparisons, and (3) applied research.

Participation in the program is required of all DOE and DOE contractor dosimetry programs (DOE Order 5480 Series). Further information with respect to the requirements and administration of DOELAP program is provided in the "Handbook for the DOE Laboratory Accreditation Program for Personnel Dosimetry Systems" and the "Quality Assurance Manual for the DOE Laboratory Accreditation Program for Personnel Dosimetry Systems" (applicable to the Performance Test Laboratory only).

Edward J. Vallario, Acting Director Radiological Controls Division

Office of Nuclear Safety

U.S. Department of Energy 


\section{CONTENTS}

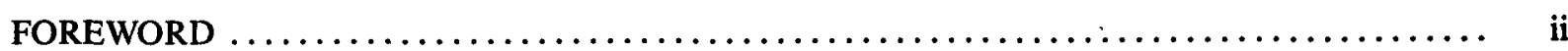

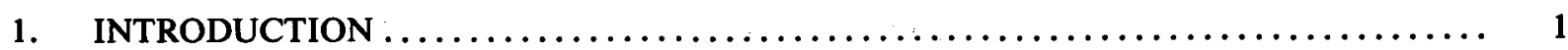

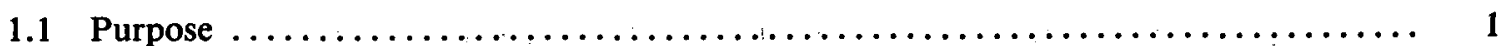

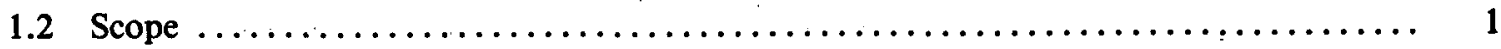

1.3 Use $\ldots \ldots \ldots \ldots \ldots \ldots \ldots \ldots \ldots \ldots \ldots \ldots \ldots \ldots \ldots \ldots \ldots \ldots \ldots \ldots \ldots \ldots \ldots \ldots \ldots \ldots \ldots \ldots \ldots, 1$

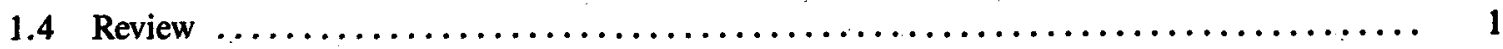

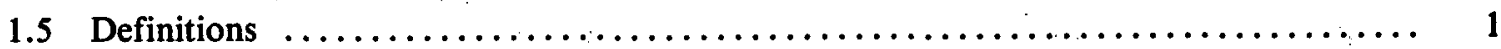

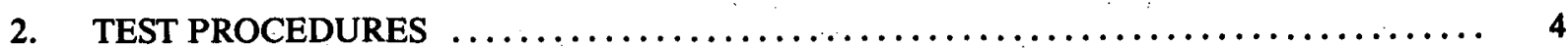

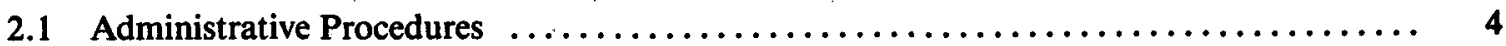

2.1.1 Information to be Supplied to the Testing Laboratory $\ldots \ldots \ldots \ldots \ldots \ldots \ldots \ldots, 4$

2.1.2 Number of Test Dosimeters $\ldots \ldots \ldots \ldots \ldots \ldots \ldots \ldots \ldots \ldots \ldots \ldots \ldots \ldots, 4$

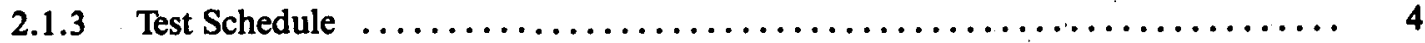

2.1.4 Dissemination of Test Results $\ldots \ldots \ldots \ldots \ldots \ldots \ldots \ldots \ldots \ldots \ldots \ldots \ldots \ldots, 4$

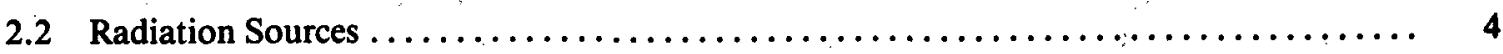

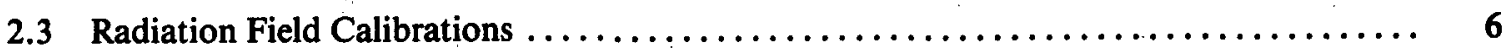

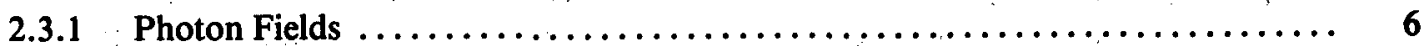

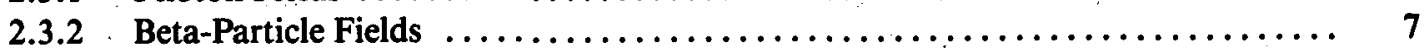

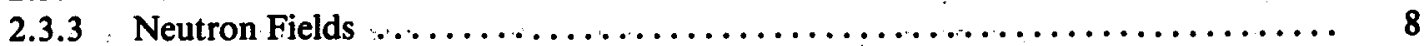

2.4 Irradiation Geometries and Uncertainties $\ldots \ldots \ldots \ldots \ldots \ldots \ldots \ldots \ldots \ldots \ldots \ldots \ldots \ldots \ldots \ldots$

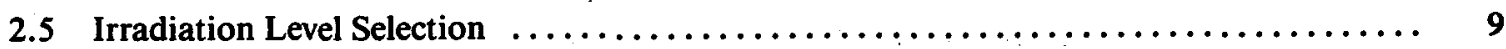

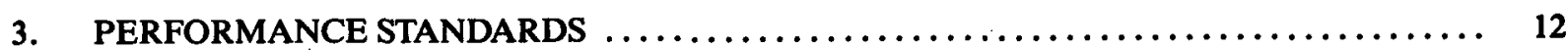

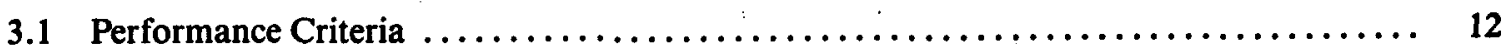

3.2 Irradiation Categories $\ldots \ldots \ldots \ldots \ldots \ldots \ldots \ldots \ldots \ldots \ldots \ldots \ldots \ldots \ldots \ldots \ldots \ldots \ldots \ldots \ldots, 13$

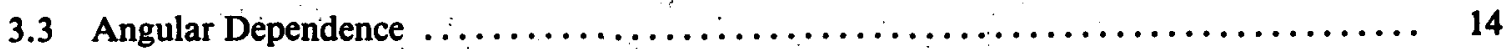

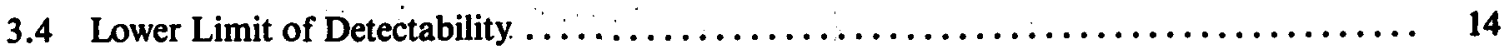

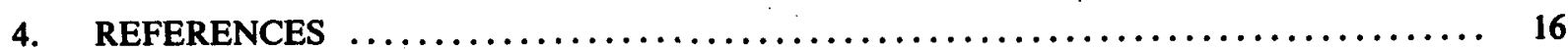

APPENDIX A-CHOICE OF REFERENCE CALIBRATION SOURCES $\ldots \ldots \ldots \ldots \ldots \ldots$

APPENDIX B-DERIVATION OF PERFORMANCE CRITERIA $\ldots \ldots \ldots \ldots \ldots \ldots \ldots \ldots \ldots$ 


\section{TABLES}

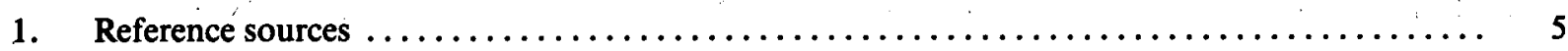

2. Exposure-to-dose-equivalent conversion factors for photons $\ldots \ldots \ldots \ldots \ldots \ldots \ldots \ldots \ldots \ldots \quad 7$

3. Dosimeter irradiation geometries $\ldots \ldots \ldots \ldots \ldots \ldots \ldots \ldots \ldots \ldots \ldots \ldots \ldots \ldots \ldots \ldots \ldots$

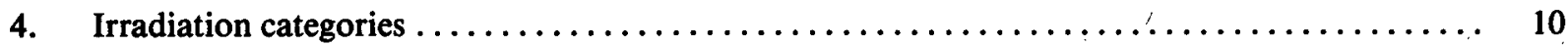




\section{DEPARTMENT OF ENERGY \\ STANDARD FOR THE PERFORMANCE TESTING OF PERSONNEL DOSIMETRY SYSTEMS}

\section{INTRODUCTION}

\subsection{Purpose}

This standard defines a set of reference performance tests to help establish a uniform approach to personnel dosimetry. The purpose of the standard is to describe minimum levels of acceptable performance and to provide procedures for the performance testing of personnel dosimetry systems.

\subsection{Scope}

The standard applies only to personnel dosimetry systems used for determining whole-body dose equivalent for the permanent record. The standard is applicable for dosimetry performed for health protection under controlled and uncontrolled conditions (accident dosimetry). Tests for accident dosimetry are approximately represented by the high-dose categories. The performance testing includes categories for the determination of dose equivalent (or absorbed dose) due to ionizing radiation only.

The standard also applies for specific energy intervals. The approximate intervals are from $15 \mathrm{keV}$ to $2 \mathrm{MeV}$ for photons, above $0.3 \mathrm{MeV}$ (average energy) for beta particles, and from $1 \mathrm{keV}$ to $2 \mathrm{MeV}$ for neutrons.

Performance studies for angular dependence (Section 3.3) and lower limit of detectability (Section 3.4) are required one time only for each dosimeter type submitted for evaluation.

NOTE: Performance tests for extremity dosimetry, thermal neutron dosimetry and high-energy neutron dosimetry are excluded from this scope. These categories are planned for inclusion in future revisions of this standard.

\subsection{Use}

Reference calibration points for personnel dosimetry systems, including energies, source specifications and standard irradiation geometries are defined in sections $2.2,2.3$, and 2.4. The perform- ance criteria defined in section 3.1 shall be used to evaluate dosimeter performance at each reference energy.

Calibrations used for the evaluation of occupational doses or dose equivalents may differ from the reference calibrations: Where such differences exist, the dosimeter's response per unit of delivered dose (or dose equivalent) for the calibration applicable to the occupational environment shall be determined relative to a reference calibration point. Determinations of calibrations specific to occupational environments shall be documented.

A facility should not be required to comply with all portions of this standard if a technical basis for exemption from identified categories is demonstrated.

\subsection{Review}

The standard shall be reviewed and updated by the Department of Energy (DOE) when considered necessary. Technological advances in both beta and neutron personnel dosimetry practices may allow strengthening of the performance specifications. In addition, it may be desirable to broaden the scope of the standard.

\subsection{Definitions}

The definitions for many of the terms used in this standard are given below:

Absorbed Dose (D). The energy absorbed per unit mass at a specified point. The special unit is the rad. The SI unit is the gray (Gy). $1 \mathrm{~Gy}=100 \mathrm{rad}$.

Accident Dosimetry. The determination of high levels of absorbed dose resulting from uncontrolled conditions. 
Accreditation. The process of evaluating a program which uses personnel dosimeters to measure, report, and record dose equivalents received by radiation workers.

Angular Dependence. The response of a dosimeter as a function of angle of incidence of the radiation detected compared to its response at normal incidence (nonperpendicular incidence).

Applicant. A DOE or DOE laboratory contractor facility which has submitted an application for DOELAP accreditation and is participating in the accreditation process. The dosimetry processor may be the same as the applicant or may be under contract to the applicant to provide the processing service.

Bias (B). The average of the performance quotients, $\mathbf{P}_{\mathbf{i}}$ for $\mathbf{n}$ dosimeters, for a specified irradiation category and depth,

$\mathrm{B}=\frac{1}{\mathrm{n}} \sum_{i=1}^{n} \mathrm{P}_{\mathrm{i}}$

Calibration Specific to Occupational Environment The dosimeter calibration applicable only to a particular occupational environment. These calibrations are determined by comparing reference measurements to dosimeter response measurements. Both measurements are performed in the work place.

Detection Threshold. The minimum evaluated dose equivalent for which the readout value of a dosimeter is significantly different (at the $95 \%$ confidence level) from the mean readout value of unirradiated dosimeters.

Dose Equivalent (H). The product of the absorbed dose (D), the quality factor (Q), and any other modifying factors. The special unit is the rem. When $D$ is expressed in $G y, H$ is in Sieverts (Sv). $1 \mathrm{~Sv}=100 \mathrm{rem}$.

Dosimeter. A combination of absorber(s) and radiation-sensitive element(s) that is used to provide a cumulative record of absorbed dose or dose equivalent received when worn by an individual.
Estimate of Uncertainty (E). The estimated fractional uncertainty of the delivered dose or dose equivalent. The value excludes uncertainties associated with the exposure-to-dose-equivalent conversion factors for photon irradiations, the flux-to-dose equivalent conversion factor for neutron irradiations and the photon component of the neutron irradiations. The testing laboratory calculates this value.

Exposure-to-Dose-Equivalent Conversion Factor for Photons $\left(C_{x}\right)$. The numerical quantity that relates the exposure in air to the dose equivalent at a specified depth in a material of specified geometry and composition. The $\mathrm{C}_{\mathrm{x}}$ factors change as a function of photon energy, material geometry (e.g., sphere, slab, or torso), and material composition (e.g., tissue-equivalent plastic, soft tissue ignoring trace elements, or soft tissue including trace elements).

Freo-Field Dose Equivalent. The dose equivalent assigned for neutron irradiation as if it were performed in free space with no background due to air and room scattering and no source asymmetry. ${ }^{5}$

High-Dose Range. A performance test range outside the normal operating range. Tests for accident dosimetry capability are conducted within this range.

In-Phantom Dose Rate for Beta Sources. The absorbed dose rate at the specified depth inside a tissue-equivalent phantom. Phantom dimensions: are assumed to be $30 \mathrm{~cm} \times 30 \mathrm{~cm} \times 5 \mathrm{~cm}$ (or greater). The tissue equivalency is for beta radiations.

Irradiation Category. Each type and energy (or. mixture) of radiation for which performance criteria are given.

Lower Limit of Detectability. The minimum evaluated dose equivalent for which the readout value of a dosimeter is significantly different (at the $95 \%$ confidence level) from the readout value at the detection threshold.

Performance Quotient $\left(\mathbf{P}_{\boldsymbol{i}}\right)$. The fractional difference between the reported and delivered absorbed dose or dose equivalent for the $\mathrm{i}^{\text {th }}$ dosimeter, 


$$
\mathbf{P}_{\mathrm{i}}=\frac{\left[\mathrm{X}_{\mathrm{i}} \text { (reported) }-\mathrm{X}_{\mathrm{i}} \text { (delivered) }\right]}{\mathrm{X}_{\mathrm{i}} \text { (delivered) }}
$$

$$
\mathrm{S}=\left[\frac{\sum_{i=1}^{n}\left(\mathrm{P}_{\mathrm{i}}-\mathrm{B}\right)_{2}}{\mathrm{n}-1}\right]^{1 / 2}
$$

where $D_{d}, H_{s}$, or $H_{d}$ can be inserted for $X$. Here $d$ and $\mathrm{s}$ refer to the depth at which $\mathrm{D}$ or $\mathrm{H}$ is specified, $d$ for deep and $s$ for shallow. The shallow absorbed dose, $D_{s}$, is not used in the performance criteria.

Processor. A supplier of personnel dosimetry services. These services include:

- Furnishing dosimeters to the user

- Evaluating the dosimeter readings after their return, in terms of the shallow and deep dose equivalent or the deep absorbed dose as prescribed in this standard

- Recording the results

- Reporting the results to the user.

Protection Dosimetry. Routine measurements and the estimation of the dose equivalent for the purpose of determining and controlling the dose equivalent received by radiation workers.

Shallow and Deep Absorbed Dose $\left(D_{s}\right.$ and $\left.D_{d}\right)$ or Dose Equivalent $\left(H_{s}\right.$ and $\left.H_{d}\right)$. The absorbed dose or dose equivalent at the respective depths of $0.007 \mathrm{~cm}$ and $1.0 \mathrm{~cm}$ in a material of specified geometry and composition.

Standard Deviation (S). The standard deviation of the performance quotients, $\mathbf{P}_{\mathrm{i}}$, calculated for $\mathbf{n}$ dosimeters for a specified irradiation category and depth,
Test. A procedure with the following sequence:

- Applicant submits dosimeters from current stock to a testing laboratory over a period of several months. The number of dosimeters submitted is sufficient for the specified irradiations in a given test category.

- Testing laboratory personnel irradiate the dosimeters using the type(s) of radiation specified for the test category.

- Applicant evaluates the response of the returned dosimeters in terms of shallow and deep dose equivalent for tests of protection monitoring or in terms of deep absorbed dose for tests in high-dose categories.

- Applicant submits these data to the testing laboratory.

- Testing laboratory analyzes the submitted data.

- Testing laboratory reports the results of this analysis (also referred to as "the test results") to the applicant.

Testing Laboratory. A laboratory independent of the applicant's operation, authorized by DOE to carry out the procedures outlined in this standard.

The words shall, should, and may are used as follows in this standard: shall denotes a requirement; practice. should, a recommendation; and may, a permissible 


\section{TEST PROCEDURES}

\subsection{Administrative Procedures}

The performance tests are administered by the testing laboratory. The administrative procedures are described below.

\subsubsection{Information to be Supplied to the Testing} Laboratory. The applicant for accreditation shall provide the following:

- The test categories desired with justification(s) for those categories not chosen

- A brief description of dosimeter design, construction, and processing

- An indication of whether the dosimeter is in current use or planned for future use

- Angular-response data required in Section 3.3 and lower limit of detectability data required in Section 3.4 or a plan indicating how these data will be obtained and furnished to the testing laboratory

- Documentation of field calibrations if different from reference sources. The differences between the procedure, calculation, and/or calibration used for reporting occupational exposures shall be provided prior to the test procedure or along with the reported data.

The applicant shall certify that the dosimeters submitted for each test are representative of those supplied routinely to its users.

2.1.2 Number of Test Dosimeters. The applicant shall submit to the testing laboratory either 15 or $\mathbf{3 0}$ dosimeters for irradiation in any given test category. Submittal of 30 dosimeters requires a special arrangement with the testing laboratory (see Section 3.1). The dosimeters shall be submitted to the testing laboratory in three shipments. Additional dosimeters shall be included with each dosimeter shipment to serve as shipment controls and replacement spares. Dosimeters may be voided in a test category because of problems caused by the testing laboratory, the applicant, or the processor. The minimum number of irradiated dosimeters required for analysis of a 15-dosimeter test is 13 and for a 30-dosimeter test is 26 . If this requirement is not satisfied, statistical analysis of the results in that category shall be delayed until replacement dosimeters have been submitted to the testing labo- ratory, irradiated, and the results are reported by the applicant to the testing laboratory.

2.1.3 Test Schedule. Each test shall extend over a period ranging from 3 to 6 months. The test dosimeters required for each test category. shall be submitted to the testing laboratory in at least three separate groups as the testing laboratory directs. Each group shall be returned by the testing laboratory to the applicant within approximately 1 month of the announced start date for irradiations. Dosimeters submitted late may be included in the following month's irradiations. The applicant shall report the evaluations to the testing laboratory within $\mathbf{4 5}$ days of receiving the dosimeters. If this requirement is not met, it may be necessary to void all dosimeter evaluations in the same test category.

2.1.4 Dissemination of Test Results. The testing laboratory shall report all test results to the applicant after the test is completed. An estimate of the uncertainty of the assigned values of the delivered dose equivalent (or absorbed dose) shall be included in the report. The applicant shall not be permitted to change or void the reported values after receiving the test results from the testing laboratory.

\subsection{Radiation Sources}

The specified irradiations represent the minimum necessary to ensure adequate performance for a multipurpose personnel dosimetry system. Most of the irradiation categories specified and the range of dose equivalents were taken from the American National Standards Institute report ANSI N13.11-1983. 1

The specifications for the test irradiations closely follow those given in ANSI N13.11. Major differences are: 1) the exposure-to-dose-equivalent conversion factors for photons $\left(C_{x}\right)$ are specified for the calibration geometry; 2) the specifications for the beta source calibrations are more complete; and 3) additional photon, beta, and neutron sources are included. A more comprehensive discussion is presented in Appendix A.

The response of the personnel dosimetry system shall be determined using the following sources: 
1. A sealed ${ }^{137} \mathrm{Cs}$ gamma-ray source

- The irradiation geometry must be adjusted to achieve a shallow depth $\mathrm{C}_{\mathrm{x}}$ factor of $1.03 \pm 0.05 \mathrm{rem} / \mathrm{R}$.

2. X-ray machine(s) that produce continuous spectra using the U.S. National Bureau of Standards (NBS) techniques ${ }^{6}$ and are capable of generating nearly monoenergetic lowenergy photon beams ( 15 to $20 \mathrm{keV}$ and 55 to $65 \mathrm{keV}$ )

- The operable voltage range is between $30 \mathrm{kV}$ and $160 \mathrm{kV}$ constant potential for the NBS techniques (Table 1). The halfvalue layer and homogeneity coefficient shall be adjusted to match NBS specifica- tions according to the recommendations in ISO 4037.7 The half-value layers shall agree to within $2 \%$ and the homogeneity coefficients within $4 \%$ of the NBS specifications.

- An ${ }^{241} \mathrm{Am}$ source may be substituted for the $55-\mathrm{keV}$ to $65-\mathrm{keV}$ nearly monoenergetic beam at the discretion of the testing laboratory.

- The k-fluorescence $x$-ray technique may be used to generate the nearly monoenergetic beams. $7-9$

3. A sealed ${ }^{90} \mathrm{Sr} /{ }^{90} \mathrm{Y}$ beta-particle source with $100-\mathrm{mg} / \mathrm{cm}^{2}$ filtration (nominal) to remove the ${ }^{90} \mathrm{Sr}$ component. It shall meet the following specifications:

Table 1. Reference sources

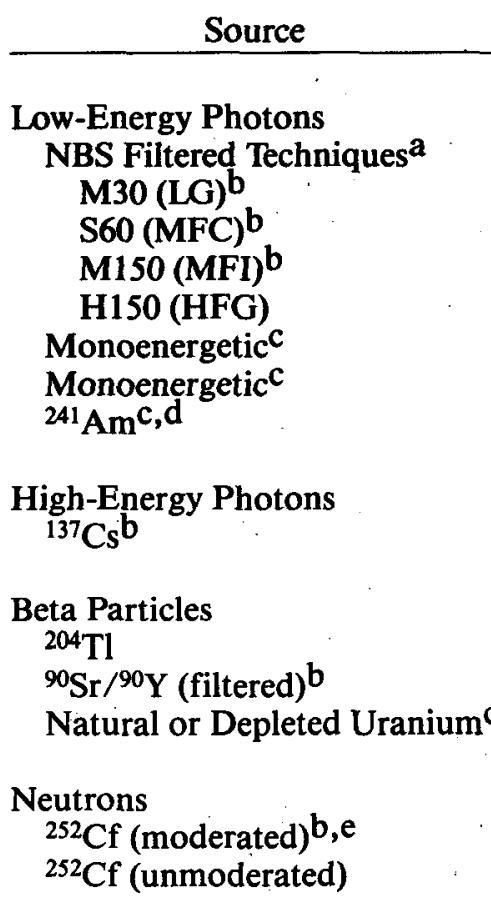

$20 \mathrm{keV}$ (average)
$36 \mathrm{keV}$ (average)
$70 \mathrm{keV}$ (average)
$120 \mathrm{keV}$ (effective)
15 to $20 \mathrm{keV}$
55 to $65 \mathrm{keV}$
$59 \mathrm{keV}$

$662 \mathrm{keV}$

$0.76 \mathrm{MeV}$ (maximum)

$2.3 \mathrm{MeV}$ (maximum)

$2.3 \mathrm{MeV}$ (maximum)

\footnotetext{
a. NBS Special Publication 250, Appendix C. ${ }^{6}$ The half-value layer and homogeneity coefficient should be adjusted according to the recommendations in ISO 4037 ?

b. These sources are also specified in ANSI N13.11-1983.1

c. These sources were included for specific occupational environments.

d. At the option of the testing laboratory, the ${ }^{241}$ Am source may be substituted for the 55- to 65-keV monoenergetic source.

e. Moderated by $15 \mathrm{~cm}$ of $D_{2} O .^{11}$
} 
- The residual maximum energy, as defined in the International Standard ISO 6980, 10 shall equal or exceed $1.80 \mathrm{MeV}$.

- The in-phantom dose rate at $100 \mathrm{mg} / \mathrm{cm}^{2}$ divided by the dose rate at $7 \mathrm{mg} / \mathrm{cm}^{2}$ shall be $1.01 \pm 0.03$.

- The in-phantom dose rate at $1000 \mathrm{mg} / \mathrm{cm}^{2}$ shall be less than $1 \%$ of the dose rate at $7 \mathrm{mg} / \mathrm{cm}^{2}$.

- The dosimetry and energy measurement specifications shall take precedence over irradiation geometry specifications.

4. A sealed ${ }^{204} \mathrm{~T} 1$ beta-particle source meeting the following specifications:

- The residual maximum energy, as defined in ISO 6980 , shall equal or exceed 0.53 $\mathrm{MeV}$.

- The in-phantom dose rate at $20 \mathrm{mg} / \mathrm{cm}^{2}$ divided by the in-phantom dose rate at $7 \mathrm{mg} / \mathrm{cm}^{2}$ shall be $0.80 \pm 0.05$.

- The dosimetry and energy measurement specifications shall take precedence over the irradiation geometry specifications.

5. A natural or depleted uranium slab meeting the following specifications:

- The source protective covering shall be in the range between $3 \mathrm{mg} / \mathrm{cm}^{2}$ and $7 \mathrm{mg} /$ $\mathrm{cm}^{2}$ inclusive.

- The dose rate at $100 \mathrm{mg} / \mathrm{cm}^{2}$ divided by the dose rate at $7 \mathrm{mg} / \mathrm{cm}^{2}$ shall be $0.58 \pm$ 0.04 .

- The in-phantom dose rate at $1000 \mathrm{mg} / \mathrm{cm}^{2}$ shall be less than $3 \%$ of the dose rate at $7 \mathrm{mg} / \mathrm{cm}^{2}$.

- The measurement specification shall take precedence over the geometry specification.

- The dimensions of the source must exceed the dimensions of the irradiated dosimeters.

6. A ${ }^{252} \mathrm{Cf}$ neutron source used unmoderated and moderated by $15 \mathrm{~cm}$ of $\mathrm{D}_{2} \mathrm{O}$ covered by $0.05 \mathrm{~cm}$ of cadmium. 11

\subsection{Radiation Field Calibrations}

- Procedures used for calibrating radiation fields shall reference them to source fields standardized by NBS and shall be consistent with accepted national standards and practices. Reference class instruments, as defined in NBS Special Publication 603,12 or sealed radioactive sources shall be used. (A list of calibration services offered by NBS is included in NBS Special Publication 250.6) The testing laboratory shall participate in a Measurement Quality Assurance Program with NBS.

The list of reference sources is given in Table 1. The rationale for selecting the reference calibration sources is discussed in Section A.1 of Appendix A. Requirements for beta calibration spectra are discussed in Section A.2 of Appendix A.

2.3.1 Photon Fields. Photon radiation fields shall be calibrated in terms of exposure in free air. Reference class ionization chambers calibrated by NBS for the particular techniques specified in Table 1 shall be used for the NBS techniques and the ${ }^{137} \mathrm{Cs}$ source. Other photon sources shall be calibrated with a reference class ionization chamber with a measured slowly varying energy dependence which has been calibrated by NBS or intercompared with NBS calibrated chambers in the appropriate energy range.

The dose equivalent assigned to exposed dosimeters shall be calculated using the exposure-to-doseequivalent conversion factors $\left(C_{x}\right)$ listed in Table 2. (The rationale used for choosing this particular set of $C_{x}$ factors is given in Appendix A, Section A.3.) Absorbed dose and dose equivalent for radioactive source irradiations shall be calculated:

$$
\begin{aligned}
& H_{s}=Q C_{x, s} \dot{X}_{a i r} t ; \quad H_{d}=Q C_{x, d} \dot{X}_{a i r} t ; \\
& D_{d}=C_{x, d} \dot{X}_{\text {air }} t
\end{aligned}
$$

where $\dot{X}_{\text {air }}$ is the exposure rate in air calibrated using the above procedure, $s$ refers to shallow, $d$ refers to deep, $\mathrm{t}$ is the irradiation time and $\mathrm{Q}$ is the quality factor (1 Sv/Gy). The shallow dose equivalent rate for ${ }^{137} \mathrm{Cs}$ exposures shall be measured for each source and the irradiation geometry shall be adjusted to achieve a $C_{x, s}$ value of $1.03 \pm 0.05 \mathrm{rem} / \mathrm{R}$. The suggested method is with an extrapolation chamber embedded in a methylmethacrylate phantom.

For $\mathrm{x}$-ray exposures referenced to an unsealed monitor ionization chamber,

$$
\begin{aligned}
& H_{s}=Q C_{x, s} T_{M C} ; \quad H_{d}=Q C_{x, d} T_{M C} C_{T P} \\
& D_{d}=C_{x, d} T M C_{T P}
\end{aligned}
$$


Table 2. Exposure-to-dose-equivalent conversion factors for photons ${ }^{a}$

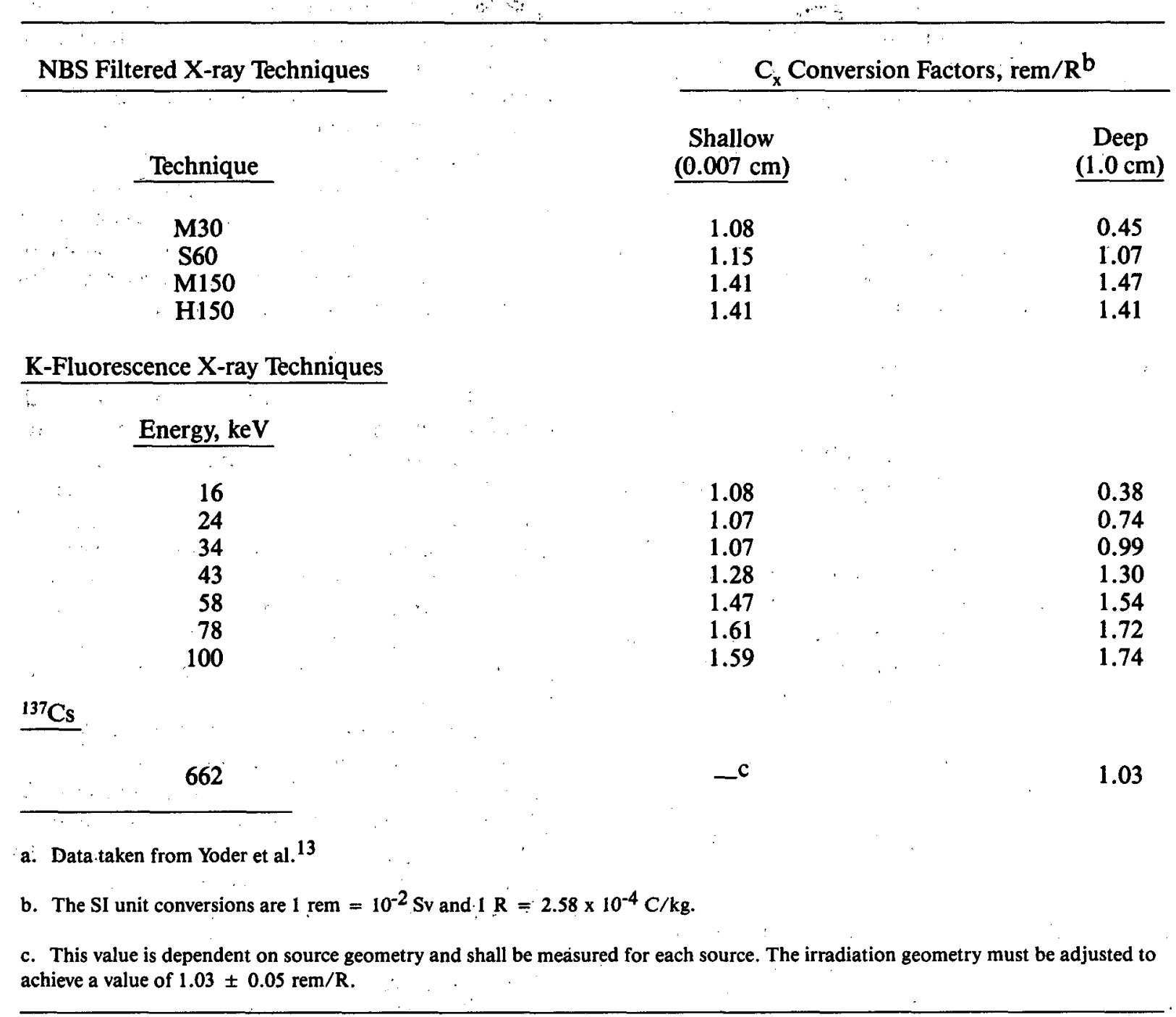

where $T$ is the exposure-per-charge calibration factor for the monitor chamber at the standard temperature and pressure; $M$ is the reading of the monitor chamber in units of charge; and $\mathrm{C}_{\mathrm{TP}}$ is the temperature and pressure correction factor for the monitor chamber.

2.3.2 Beta-Particle Fields. Beta-particle fields shall be calibrated in terms of absorbed dose at a tissue depth of $7 \mathrm{mg} / \mathrm{cm}^{2}$, using a thin-window, tissue-equivalent extrapolation chamber with the appropriate thickness of tissue-equivalent material in front of the window. The extrapolation chamber shall be calibrated using a beta-particle source with a calibration referenced to standards maintained by NBS. A tissue-equivalent extrapolation chamber typically contains a shell, a collecting electrode, and a front window of tissue-equivalent plastic. If air is used in the volume, an appropriate correction factor (stopping power ratio) shall be required.

Calibration depths used for beta irradiations can range from a few tenths of milligrams per square centimeter to $7 \mathrm{mg} / \mathrm{cm}^{2}$. If a source has been calibrated at depths other than $7 \mathrm{mg} / \mathrm{cm}^{2}$, measurement of a transmission factor shall be performed. The transmission factor shall be measured with a thin-window ionization chamber or extrapolation chamber. The chamber shall be positioned with its effective center at the calibrated point. Measurements shall then be performed at the depth of calibration and at a depth of $7 \mathrm{mg} / \mathrm{cm}^{2}$. If material must be added to reach the required measurement depth, it shall be placed in contact with the chamber window. The total material thickness should be within $\pm 0.5 \mathrm{mg} / \mathrm{cm}^{2}$ of the nominal measurement depth or measurement data collected with greater 
and lesser thicknesses shall be used to obtain the correct value by interpolation. The transmission factor shall be calculated as follows:

$$
C_{\text {trans }}=\frac{\dot{X}\left(7 \mathrm{mg} / \mathrm{cm}^{2}\right)}{\dot{X}(d)}
$$

where $\dot{X}$ is the relative chamber signal, corrected for temperature and pressure, and $d$ is the original calibration depth.

The dose equivalent assigned to exposed dosimeters shall be calculated using

$\mathrm{H}_{\mathrm{s}}=\dot{\mathrm{D}}_{\mathrm{t}}(\mathrm{d}) \cdot \mathrm{t} \cdot \mathrm{Q} \cdot \mathrm{C}_{\text {trans }}$

where $\dot{D}_{t}$, is the absorbed dose rate at the calibration depth $d, t$ is the time, and $Q$ is the quality factor (1 Sv/Gy).

2.3.3 Neutron Fields. The ${ }^{252} \mathrm{Cf}$ sources shall be calibrated in terms of neutron emission rate by NBS or another qualified laboratory using equipment and techniques referenced to NBS-maintained standards. Procedures for calculating the dose equivalent for exposed dosimeters shall follow NBS Special Publication 633.5 In this publication the free-field dose equivalent (mrem) for unmoderated exposures is defined by:

$H_{d}=\frac{N \cdot C_{U} \cdot t \cdot 3600}{4 \pi r^{2}}$

where $\mathrm{N}$ is the neutron emission rate $(\mathrm{n} / \mathrm{sec}), \mathrm{C}_{\mathrm{U}}$ is the dose-equivalent conversion factor for unmoderated ${ }^{252} \mathrm{Cf}\left(3.33 \times 10^{-5} \mathrm{mrem}-\mathrm{cm}^{2} / \mathrm{n}\right), \mathrm{t}$ is the time (h), 3600 is the number of seconds in an hour, and $\mathrm{r}$ is the calibration distance (from the source center to the front face of the phantom, $\mathrm{cm}$ ). For the moderated source,

$H_{d}=\frac{N \cdot C_{M} \cdot t \cdot 3600 \cdot 0.885}{4 \pi r^{2}}$

where $C_{M}$ is the dose-equivalent conversion factor for moderated ${ }^{252} \mathrm{Cf}\left(9.08 \times 10^{-6} \mathrm{mrem}-\mathrm{cm}^{2} / \mathrm{n}\right)$, and the $\mathbf{0 . 8 8 5}$ factor allows for the loss of the number of neutrons moderated below the cadmium cutoff. 14

NOTE: Ing and Cross 15 quote slightly different values for $C_{M}$ because they use a lower limit of $1 \mathrm{eV}$ for their calculations. The effect of the neutrons between the cadmium cutoff and $1 \mathrm{eV}$ account for differences in $C_{M}$ and the neutron loss fraction (see explanation in Schwartz, Eisenhauer and Grundl ${ }^{16}$ ).

The applicant can obtain direct calibration factor(s) from the testing laboratory. Otherwise, the applicant should consider applying correction factors to the dosimeter readings for air scattering, room return, and source scattering. These techniques are described in NBS Special Publication 633.5

The photon component for each irradiation source geometry shall be measured. Unmoderated ${ }^{252} \mathrm{Cf}$ irradiations probably have a greater variation of photon component than the moderated irradiations because of greater relative differences in source filtration. Typical values are $7 \%$ of the neutron dose equivalent for unmoderated irradiations ${ }^{17}$ and $18 \%$ for moderated irradiations. ${ }^{18}$

\subsection{Irradiation Geometries and Uncertainties}

The dosimeters shall be irradiated using a phantom backing, except for on-contact slab-source exposures. The phantom shall be methylmethacrylate slabs measuring $30 \mathrm{~cm} \times 30 \mathrm{~cm} \times 15 \mathrm{~cm}$ for photon calibrations; $30 \mathrm{~cm} \mathrm{\times} 30 \mathrm{~cm} \times 5 \mathrm{~cm}$ (or greater) for beta-particle calibrations, and $40 \mathrm{~cm} \times 40 \mathrm{~cm} \times 15 \mathrm{~cm}$ for neutron calibrations. The dosimeters shall be attached to the surface of the phantom facing the source (front face). For collimated beams, the central beam axis is positioned perpendicular to and passing through the center of the front face of the phantom. For uncollimated beams, the center of the front face of the phantom is positioned perpendicular to a radial line from the source center. Dosimeters shall be mounted with the sensitive elements within the central $15-\mathrm{cm} \times 15-\mathrm{cm}$ area of the phantom for photon and beta-particle irradiations and within the central $20-\mathrm{cm} \times 20-\mathrm{cm}$ area for neutron irradiations. The point of calibration shall coincide with the center of the front face of the phantom. The irradiation geometries summarized: in Table 3 shall be used.

For photon and beta-particle irradiations, the scatter from the surfaces of the irradiation room and from the source and phantom support hardware shall contribute only a small fraction to the uncertainty in the assigned dose equivalent. If several dosimeters are irradiated simultaneously, precautions shall be taken to keep the mutual interference much smaller than the uncertainty in the assigned dose equivalent. 
Table 3. Dosimeter irradiation geometries

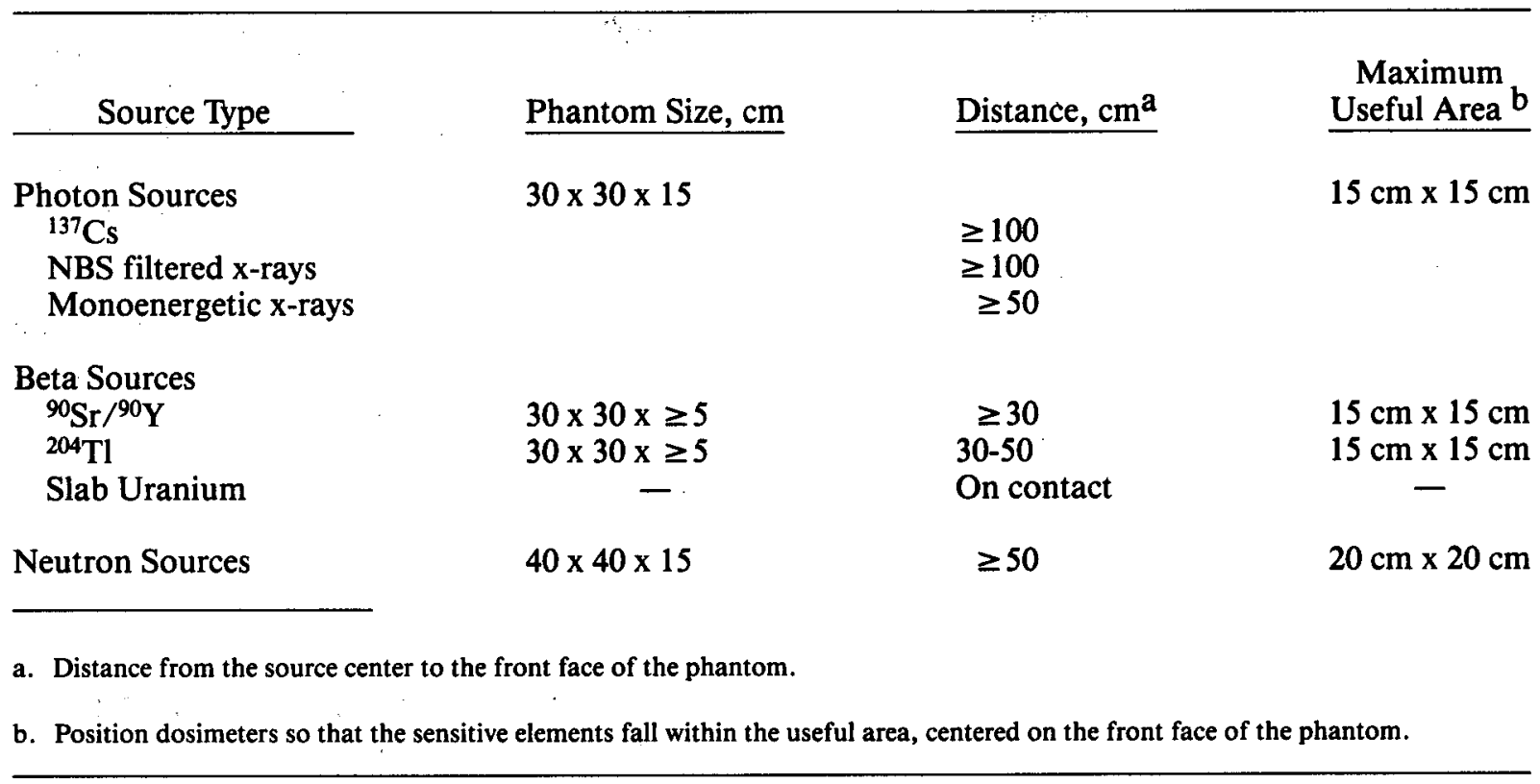

The uncertainty in the assigned dose equivalent shall not exceed $\pm 5 \%$, excluding uncertainties in the dose equivalent conversion factors and the photon component of the neutron irradiations. Doserate uniformity measurements shall be performed to determine the useful exposure area. Included in the $5 \%$ limit are uncertainties due to source standardization, the uncertainty due to dosimeter position, and the uncertainty due to scattered radiation not stemming from the phantom. The systematic and random uncertainties shall be summed quadratically and separately. The $\pm 5 \%$ limit shall be imposed on the total linear sum of the systematic and random uncertainties. (Refer to Chapter 23 of NBS Handbook $91^{19}$ for guidance on quoting uncertainties.)

NOTE: To achieve a total uncertainty not in excess of $\pm 5 \%$, it may be necessary to measure and use position-specific correction factors. This can reduce the contribution to the total uncertainty due to dose-rate nonuniformity to an acceptable level.:

\subsection{Irradiation Level Selection}

In each category, the irradiation levels shall be chosen at random using the logarithms of the dose equivalents or absorbed doses. Random selection of the logarithms of the irradiation levels rather than the levels themselves increases the probability of selecting values near the lower limit of the range. Values for the 1-cm depth shall be used except for the beta-particle category or mixtures using beta sources, for which the shallow depth shall be used. In addition, for the categories dealing with mixed radiation fields, the component ratios shall be selected at random. In these categories, the assigned dose equivalent of the larger component shall not be greater than three times that of the smaller component. The test range for the mixture categories specified in Table 4 applies to the summed dose equivalent.

The method for selecting irradiation levels within any one test category and test irradiation range shall be to select random numbers, $\rho$, between 0 and 1 and to represent the logarithm of the dose equivalent, $H$, as

$\log \mathrm{H}=\log (\mathrm{H})_{\ell}+\rho\left[\log (\mathrm{H})_{\mathrm{u}}-\log (\mathrm{H})_{\ell}\right]$

where $(\mathrm{H})_{\ell}$ and $(\mathrm{H})_{\mathrm{u}}$ are the lower and upper limits, respectively, of the range of test irradiation levels in question. The logarithms of absorbed doses shall also be selected using the same method. 
Table 4. Irradiation categories

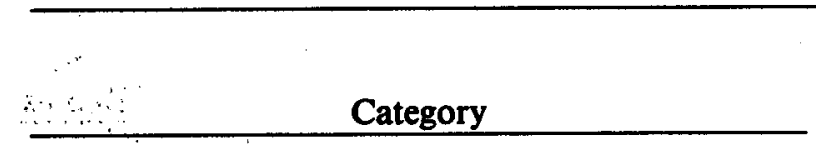

I. Low-Energy Photons (X Ray) - High Dose

NBS Filtered Technique

$$
\text { M150a }
$$

II. High-Energy Photons - High Dose

$$
{ }^{137} \mathrm{Cs}^{\mathrm{a}}
$$

IIIA. Low-Energy Photons (X Ray) - General

NBS Filtered Techniques

$$
\begin{aligned}
& \text { M30a } \\
& \text { S60a } \\
& \text { M150a } \\
& \text { H150 }
\end{aligned}
$$

IIIB. Low-Energy Photons (X Ray) Plutonium Environments

Monoenergetic

Monoenergetic

${ }^{241} \mathrm{Am}^{\mathrm{d}}$

IV. High-Energy Photons

$$
{ }^{137} \mathrm{Cs}^{\mathrm{a}}
$$

VA. Beta Particles - General (Point Geometry)

$$
{ }^{204} \mathrm{Tl}{ }^{\mathrm{e}} \mathrm{Sr} /{ }^{90} \mathrm{Y} \text { (filtered) } \mathrm{a}
$$

VB. Beta Particles - Special (Slab Geometry)

$$
\text { Uranium }
$$

Test

Energy Test Range

Depths

$10-500 \mathrm{rad}$

Deep

$70 \mathrm{keV}^{\mathrm{b}}$

$10-500 \mathrm{rad}$

Deep

$662 \mathrm{keV}$

$$
\text { 0.03-10 rem } \begin{aligned}
& \text { Shallow } \\
& \text { Deep }
\end{aligned}
$$

$20 \mathrm{keV}^{\mathrm{b}}$

$36 \mathrm{keV}^{\mathrm{b}}$

$70 \mathrm{keVb}$

$120 \mathrm{keV}^{\mathrm{c}}$

0.03-5 rem

Shallow Deep

15 to $20 \mathrm{keV}$

55 to $65 \mathrm{keV}$

$59 \mathrm{keV}$

0.03-10 rem Shallow

Deep

$662 \mathrm{keV}$

0.15-10 rem Shallow

$0.76 \mathrm{MeVf}^{\mathrm{f}}$
$2.3 \mathrm{MeVf}^{\mathrm{f}}$

0.15-5 rem Shallow

2.3 $\mathrm{MeV}^{\mathrm{f}}$ 
Table 4. (continued)

\section{Category}

VC. Beta Particles - Special (Point Geometry)

$$
{ }^{204} \mathrm{TP}^{\mathrm{e}}
$$$$
{ }^{90} \mathrm{Sr} /{ }^{90} \mathrm{Y}
$$

VI. Neutron

$$
\begin{aligned}
& { }^{252} \mathrm{Cf} \text { (moderated) } \\
& { }^{252} \mathrm{Cf} \text { (unmoderated) }
\end{aligned}
$$

VII. Mixture Categories

III \& IVa

III \& V

IV \& Va

III \& VIh

IV \& VIa
Test

Energy

$\underline{\text { Test Range }}$

Depths

0.15-10 rem Shallow

$0.76 \mathrm{MeV}^{\mathrm{f}}$

2.3 $\mathrm{MeV}^{\mathrm{f}}$

$0.2-5 \mathrm{rem}$

Deep

One energy

from each

category

$\begin{array}{ll}\left.\begin{array}{l}0.05-5 \mathrm{rem} \\ 0.2-5 \text { rem } \\ 0.2-5 \text { rem }\end{array}\right\} & \begin{array}{l}\text { Shallow, } \\ \text { Deep } \\ 0.3-5 \text { rem }\end{array} \\ 0.3-5 \text { rem } & \text { Deep } \\ & \text { Deep }\end{array}$

a. This category or a subset of this category is also specified in Reference 1 .

b. Average.

c. Effective.

d. The ${ }^{241} \mathrm{Am}$ source is optional. At the option of the testing laboratory, it may be used in lieu of the 55- to $65-\mathrm{keV}$ monoenergetic source.

e. A modified performance algorithm is recommended.

f. Maximum:

g. Moderated by $15 \mathrm{~cm}$ of $\mathrm{D}_{2} \mathrm{O}$ (see Reference 11 ).

h. For work environments containing plutonium, use the monoenergetic or ${ }^{241} \mathrm{Am}$ sources. 


\section{PERFORMANCE STANDARDS}

\subsection{Performance.Criteria}

Performance in a given category or subcategory (see Table 4) shall be considered adequate if, for the shallow and/or deep dose equivalents (or the deep absorbed dose)

$|\mathrm{B}|+\mathrm{S}-|\mathrm{E}| \leq \mathrm{L}$

where $B$ and $S$ designate, respectively, the bias and standard deviation of the performance quotient for the particular category or subcategory, $E$ is the estimation of the fractional uncertainty in the delivered dose or dose equivalent rate, and $L$ is the tolerance level. The values of $\mathrm{L}$ shall be the following:

$\mathbf{L}=\mathbf{0 . 3 0}$ for Categories I through VI

$L=\mathbf{0 . 4 0}$ for Category VII.

A modified performance criterion in lieu of Equation (11) shall be acceptable for the ${ }^{204} \mathrm{Tl}$ tests. The ${ }^{204} \mathrm{Tl}$ source shall not be used for mixtures (Category VII). The modified criterion is:

$|\mathrm{B}|-|\mathrm{E}| \leq 0.40\left({ }^{204} \mathrm{Tl}\right.$ only $)$

The performance criteria in Equations (11), (12) and (13) shall be used until two years after the effective date of the DOE Order. ${ }^{20}$ At that time, Equation (12) shall be changed to: " $L=0.30$ for all categories" and Equation (13) shall be deleted. The performance criteria for ${ }^{204} \mathrm{Tl}$ shall then be the same (including mixtures) as for the other test sources.

NOTE: The standard of performance is based on achievable standards consistent with the goals of health protection. The test criterion,

$|\mathrm{B}|+\mathrm{S} \leq 0.30$

can be interpreted as providing approximately $70 \%$ confidence that a dosimeter response would be within $30 \%$ of a conventionally true value. However, for workers using four dosimeters annually and receiving approximately the same dose on each, the criterion provides approximately 95\% confidence that the annual reported dose equivalent would be within $30 \%$ of a conventionally true value. The relationship of this criterion to the recommendations of the National Council on Radiation Protection and Measurements, the International Commission on Radiation Units and Measurements and the International Commission on Radiological Protection are contained in Appendix B.

The estimation of uncertainty $(E)$ was included in the test algorithm to decrease the probability of an inadequate test result being assigned to an adequate dosimetry system. The test applicant receives the benefit of the uncertainty in the delivered dose or dose equivalent.

The ability of a dosimetry system to meet the performance criteria is typically limited by the mixture categories, especially those mixed with the low energy photon category. The tolerance level for mixture categories was set to 0.40 from 0.30 for the first two-year testing period to allow for unexpected difficulties and provides time for adjustments to meet the more stringent criteria to be imposed later.

The test for the low-energy beta source $\left({ }^{204} \mathrm{Tl}\right)$ is not required to use Equation (11) for the initial two-year period because of the technological and practical limitations of current dosimeter designs. The ${ }^{204} \mathrm{Tl}$ test algorithm was chosen based on the low-energy beta performance reported by Roberson et al. ${ }^{3}$

The number of dosimeters submitted for a category may be doubled (from 15 to 30 ) if the fractional standard deviation for that category is greater than 0.15 . Determining which categories qualify is the responsibility of the applicant, with concurrence by the testing laboratory (see Section 2.1.2). If the performance of a dosimetry system is found inadequate at the conclusion of a performance test and the estimated probability is greater than $5 \%$ that the inadequate result was due to statistical fluctuations in the testing procedure, it shall be so noted on the test results and the applicant should consider submitting $\mathbf{3 0}$ dosimeters to that category during the subsequent retest period.

NOTE: The statistical uncertainty of the test results increases with the standard deviation (see Appendix B). Table B.1 of Appendix B lists the (approximate) two standard deviation uncertainties of the test result as a function of the true dosimeter standard deviation and the number of dosimeters used. These values may be used to estimate the probability of an inadequate performance due to 
the uncertainties in the test results. Doubling the number of test dosimeters will decrease the effects of the test uncertainties.

The performance test shall be split into three parts in a period not shorter than 3 months and not longer than 6 months (see Section 2.1.3).

NOTE: The standard deviation is composed of dosimeter variations present in a batch of dosimeters read sequentially and the long-term variability of the calibration-plus-readout process. A sampling of the long-term variability is accomplished by splitting the evaluation over a period of time.

\subsection{Irradiation Categories}

The evaluation of the personnel dosimetry system shall use the categories listed in Table 4. The applicants shall submit dosimeters for testing in the high-dose categories (I and II) corresponding to the similar protection categories (III and IV).

NOTE: The high-dose category corresponding to Category HIB is Category I due to the difficulty of achieving high-dose levels with nearly monoenergetic sources.

The nearly monoenergetic low-energy photon sources (Category IIIB), the uranium slab source (Category VB), and the special beta point sources (Category VC) were included for application to specific occupational environments. These categories may be used in place of or in addition to Categories IIIA and VA, depending on the occupational environments included in the service. Dosimetry services for an occupational environment containing significant quantities of plutonium shall use Category. IIIB. If the same service covers areas with general $\mathrm{x}$-ray sources, Category IIIA shall also be used.

Dosimetry services covering occupational environments containing uranium sources and having an established beta calibration program using slab uranium may use Category VB in place of VA. If the dosimetry service also covers environments with general beta emitters, then testing in Category VA shall be performed.

Category VC shall be used by contractors requiring either a high-energy or low-energy beta source test only. The desired source shall be specified before initiation of the performance test. If both high- and low-energy sources are required, Category VA shall be used. If both low-energy photon categories (IIIA and IIIB) or if two of the beta categories (VA, VB, and/or VC) are required, the dosimetry system may use different algorithms corresponding to those used for the different occupational environments.

If an applicant participates in both low-energy photon categories (IIIA and IIIB) or two of the beta categories (VA, VB and VC) and uses the same algorithms for both categories, then only 5 dosimeters shall be submitted for each corresponding mixture category involving those categories. The spectra for those mixture irradiations shall be selected at random from the combined category. If an applicant participates in both low-energy photon categories (IIIA and IIIB) or two of the beta categories (VA, VB and VC) using different algorithms for each category, then 10 dosimeters shall be submitted for each mixture, 5 for each category. In such cases, the applicant shall submit results using both algorithms. The testing laboratory shall choose only the appropriate irradiation categories for the performance test for each algorithm.

NOTE: Categóry VC was included to accommodate special dosimetry environments. It is expected that the choice of Category VC will be accompanied by a justification. Field measurement data may be required.

The radiation source from Category IIIA and each mixture category involving IIIA shall be chosen for each of the three testing parts at random without replacement. The choice of sources from Category IIIB and each mixture category involving IIIB will alternate for each test part. For each of the Categories IIIA, IIIB, IV, VA, VB, and VC and the mixture categories not using neutrons, the category used for individual irradiated dosimeters shall not be identified to the applicant until after test results are reported to the applicants. In addition, the sources used for the low-energy photon irradiations and the Category VA beta particle irradiations shall not be divulged until the test results are reported.

An applicant participating in neutron tests shall specify which neutron source most appropriately represents the spectral composition of occupational neutron fields which the dosimetry program covers. If both sources are required to adequately represent these neutron fields, the performance testing shall include both sources. The applicant may identify in advance the dosimeters submitted for the neutron tests. When the dosimeters are 
returned for evaluation, the participant shall be told which dosimeters were irradiated with neutrons and which source was used. The testing laboratory shall provide pretest calibration exposures for the neutron sources upon request. The testing laboratory shall also provide the ratio of readings from a 9-in.-diameter spherical rem meter and a 3-in.-diameter sphere covered with 10-mil-thick cadmium as a relative calibration for albedo dosimeters. 21

NOTE: This standard directs the testing laboratory to provide the calibration factor for the neutron performance tests to the applicant. The bias should indicate the ability to calibrate the dosimetry system to an external source. The dosimeter response relative to the testing source(s) and the occupational environments must be documented (see Section 1.3).

\subsection{Angular Dependence}

For each dosimeter design submitted for testing and for each type of radiation in Categories III through VI for which performance is tested, a study of dosimeter performance when the incident radiation is nonperpendicular shall be carried out once. The study need not be a part of a test series or performed by the testing laboratory. At least two different radiation spectra shall be used in Category IIIA and IIIB; low and mid-range energies should be considered. Category VB is excluded from this requirement. The study procedure is given below. No performance criteria shall be applied to the results of this study.

Procedure for Angular Dependence Study. Mount the dosimeters on the front face of the phantom specified for the performance tests. Give identical irradiations to at least two dosimeters of each kind. Vary the angle of incidence in two planes perpendicular to each other and to the plane of the dosimeter in the original test configuration. Vary the angle by rotating the phantom through the appropriate angle. To achieve rotations along the horizontal axis of the dosimeter, rotate the dosimeter $90^{\circ}$ on the phantom and rotate the phantom along its vertical axis.

At least seven different angles of incidence from $-85^{\circ}$ to $+85^{\circ}$, including $0^{\circ}$ (perpendicular incidence), shall be used in each of the two planes. Values for the dose equivalent for each irradiation exposure should be approximately $500 \mathrm{mrem}$. For a given angle of incidence and type and energy of incident radiation, the results of the angular dependence study shall be expressed as the ratio of the applicant's dose equivalent interpretation to the actually administered dose equivalent obtained on the basis of perpendicular incidence.

\subsection{Lower Limit of Detectability}

For each dosimeter design submitted for testing and for at least one source in Categories III through VI for which performance is tested, a study to determine the lower limit of detectability shall be conducted once and reported to the testing laboratory. The study need not be part of a test series or performed by the testing laboratory. The study procedure is given below. No performance criteria shall be applied to the results of this study.

Procedure for the Lower Limit of Detectability Study. At least 10 dosimeters for irradiation per category, plus 10 dosimeters for background evaluation, for each dosimeter design, shall be selected from the routine-processed pool of dosimeters for this study. The dosimeters shall be placed in an unshielded environment for a time sufficient to obtain an unirradiated background signal typical for routine processed dosimeters. At least ten dosimeters shall be irradiated for each category to a dose significantly greater (e.g., $500 \mathrm{mrem}$ ) than the estimated lower limit of detectability. Both the irradiated and unirradiated dosimeters shall be processed and evaluated. The following quantities shall be calculated:

$$
\begin{aligned}
& \mathrm{H}_{\mathrm{o}}=\frac{1}{\mathrm{n}} \sum_{i=1}^{n} \mathrm{X}_{\mathrm{io}} \\
& \mathrm{S}_{\mathrm{o}}=\left[\frac{1}{\mathrm{n}-1} \sum_{i=1}^{n}\left(\mathrm{X}_{\mathrm{io}}-\mathrm{H}_{\mathrm{o}}\right)^{2}\right]^{1 / 2} \\
& \mathrm{H}_{1}=\frac{1}{\mathrm{n}} \sum_{i=1}^{n} \mathrm{X}_{\mathrm{il}} \\
& \mathrm{S}_{1}=\left[\frac{1}{\mathrm{n}-1} \sum_{i=1}^{n}\left(\mathrm{X}_{\mathrm{il}}-\mathrm{H}_{\mathrm{1}}\right)^{2}\right]^{1 / 2}
\end{aligned}
$$

where $X_{i o}=$ unirradiated dosimeter values and $X_{i}$ $=$ irradiated dosimeter values. The values $H_{o}$ and $\mathrm{H}_{1}$ are the mean evaluated dose equivalent values 
for the unirradiated and irradiated dosimeters, respectively, and $S_{0}$ and $S_{1}$ are the associated standard deviations. The dosimeter readings shall be processed through the dose algorithms without truncation or distortion (i.e., do not zero any readings). If a background is subtracted, negative values shall be retained for the calculation of $S_{0}$. The algorithms for the calculation of shallow and/or deep dose equivalent shall be used to calculate $\mathrm{H}_{\mathrm{o}}$ and $\mathrm{H}_{\mathrm{l}}$, depending on the category test specifications. The lower limit of detection, $L_{D}$ shall be calculated as follows:

$$
\begin{aligned}
L_{D}= & 2\left[t_{p} S_{o}+\left(t_{p} S_{1} / H_{1}\right)^{2} H_{o}^{\prime}\right] / \\
& {\left[1-\left(t_{p} S_{1} / H_{1}\right)^{2}\right] }
\end{aligned}
$$

where $t_{p}$ is the $t$ distribution for $n-1$ degrees of freedom and a $p$ value of 0.95 (see NBS Handbook $91^{19}$ ) and $\mathrm{H}_{\mathrm{o}}^{\prime}$ is the average of the unirradiated dosimeter values without subtracting a background signal.

Alternate Method. If the performance testing was completed within six months of this study, then the values of $B$ and $S$ may be used to calculate $[1.75 \times \mathrm{S} /(1+B)]$ which may be used in place of $t_{p} S_{1} / H_{1}$ in Equation (19) for each category. Only a set of unirradiated dosimeters would be required to determine $L_{D}$.

NOTE: Equation (19) is based on the desire to minimize both false negative and false positive results. All values below the detection threshold should be set to zero. For example, $t_{p} S_{0}$ for $p=$ 0.95 is an estimate of the detection threshold allowing $5 \%$ false positive values. For the lower limit of detection false negative values are also minimized. For $\mathrm{p}=0.95$, the probability of no more than $5 \%$ false positive and false negative values provides a lower limit of detection of:
$\mathrm{L}_{\mathrm{D}}=\mathrm{t}_{\mathrm{p}, \mathrm{o}} \mathrm{S}_{\mathrm{o}}+\mathrm{t}_{\mathrm{p}, \mathrm{D}} \mathrm{S}_{\mathrm{D}}$

where $S_{D}$ is the standard deviation at the lower limit of detectability and $t_{p, o}$ and $t_{p, D}^{\prime}$ depend on the number of dosimeters used to estimate $S_{0}$ and $S_{D}$, respectively.

Equation (20) is an estimate of the equation

$\mathbf{L}_{\mathrm{D}}=\mathrm{K}_{\mathrm{p}} \sigma_{\mathrm{o}}+\mathrm{K}_{\mathrm{p}} \sigma_{\mathrm{D}}$

where $\sigma_{o}$ and $\sigma_{D}$ are the true standard deviations and $K_{p}$ is the abscissa of the standard normal distribution below which the total relative area under the curve is $\mathrm{P}$. The $\sigma_{\mathrm{D}}$ value is composed of the fluctuation of the background $\left(\sigma_{0}\right)$ and the fluctuation inherent in the readout process. If $\sigma_{1} / \mathrm{H}_{1}$ is the relative standard deviation at high doses, then

$\sigma_{\mathrm{D}}^{2} \simeq \sigma_{\mathrm{o}}^{2}+\left(\frac{\sigma_{1}}{\mathrm{H}_{1}}\right)^{2}\left(\mathrm{~L}_{\mathrm{D}}^{2}+2 \mathrm{~L}_{\mathrm{D}} \mathrm{H}_{\mathrm{O}}\right)$

and solving for $\mathrm{L}_{\mathrm{D}}$,

$$
\begin{aligned}
\mathrm{L}_{\mathrm{D}}= & 2\left[\mathrm{~K}_{\mathrm{p}} \sigma_{\mathrm{o}}+\left(\mathrm{K}_{\mathrm{p}} \frac{\sigma_{1}}{\mathrm{H}_{1}}\right)^{2} \mathrm{H}_{\mathrm{o}}\right] / \\
& {\left[1-\left(\mathrm{K}_{\mathrm{p}} \frac{\sigma_{1}}{\mathrm{H}_{1}}\right)^{2}\right] }
\end{aligned}
$$

Using $t_{p}$ for $K_{p}$ and $S$ for $\sigma$, Equation (19) is obtained. If $t_{p, o}$ is not equal to $t_{p, D}$, the formula for $L_{D}$ is not exact, but should be a close approximation. Additional information can be found in an article by Currie. 22 


\section{REFERENCES}

1. American National Standards Institute (ANSI), American National Standard, Criteria for Testing Personnel.Dosimetry Performance, ANSI N13.11-1983, New York, New York, 1983.

2. Roberson, P. L., and Holbrook, K. L, Guidelines for the Calibration of Personnel Dosimeters, PNL4515, Pacific Northwest Laboratory, Richland, Washington, 1984.

3. Roberson, P. L., Holbrook, K. L., Yoder, R. C., Fox, R. A., Hadly, R. T., Hogan, B. T., and Hooker, C. D., Performance Comparisons of Selected Personnel Dosimetry Systems in Use at Department of Energy Facilities, PNL-3983, Pacific Northwest Laburatory, Richland, Washington, 1983.

4. Carlson, R. D. and Gesell, T. F., The Department of Energy Laboratory Accreditation Program in Personnel Dosimetry: Results of the Pilot Performance Test, DOE/ID-12104, U. S. Department of Energy, Idaho Operations Office, Idaho Fälls, Idaho, 1986.

5. Schwartz, R. B., and Eisenhauer, C. M., Procedures for Calibrating Neutron Personnel Dosimeters, NBS Special Publication 633, U.S. Department of Commerce, National Bureau of Standards, Washington, D.C., 1982.

6. U.S. National Bureau of Standards (NBS), NBS Calibration Services Users Guide, NBS Special Publication 250, U.S. Government Printing Office, Washington, D.C., 1986.

7. International Organization for Standardization (ISO), $X$ and $\gamma$ Reference Radiations for Calibrating Dosimeters and Dose Ratemeters and for Determining Their Response as a Function of Photon Energy, ISO 4037, UDC 535-34-36:53.089.6, Geneva, Switzerland, 1979.

8. Larson, H. V., Myers, I. T., and Roesch, W. C., A Wide Beam Fluorescent X-Ray Source, HW31781, Hanford Atomic Products Operation, Richland, Washington, 1954.

9. Kathren, R. L., Rising, F. L., and Larson, H. V., "K-Fluorescence X-Rays: A Multi-Use Tool for Health Physics," Health Phys., 1971, 21:285-293.

10. International Organization for Standardization (ISO), Reference Beta Radiations for Calibrating Dosemeters and Doseratemeters and for Determining Their Response as a Function of Beta Radiation Energy, ISO 6980-1984, Geneva, Switzerland, 1984, UDC 535-34:539.165:53.089.6.

11. Schwartz, R. B. and Eisenhauer, C. M., The Design and Construction of a $\mathrm{D}_{2} \mathrm{O}$-Moderated ${ }^{252} \mathrm{Cf}$ Source for Calibrating Neutron Personnel Dosimeters Used at Nuclear Power Reactors, NUREG/CR1024, U.S. Nuclear Regulatory Commission, Washington, D.C., 1980.

12. U.S. National Bureau of Standards (NBS), Requirements for an Effective National Radiation Measurements Program, NBS Special Publication 603, U.S. Government Printing Office, Washington, D.C., 1981.

13. Yoder, R. C., Bartlett, W. T., Courtney, J. W., Hooker, C. D., Holland, J. A., and Hogan, B. T., Confirmation of Conversion Factors Relating Exposure and Dose-Equivalent Index Presented in ANSI N13.11, NUREG/CR-1057, PNL-3219, Pacific Northwest Laboratory, Richland, Washington, 1979.

14. Eisenhauer, C. M., "Evaluation of Dose Equivalent per Unit Fluence for a $\mathrm{D}_{2} \mathrm{O}-\mathrm{Moderated}{ }^{252} \mathrm{Cf}$ Neutron Source," Radiat. Prot. Dosim., 1984, 9:63-64. 
15. Ing, H., and Cross, W. G., "Spectral and Dosimetric Characteristics of a $\mathrm{D}_{2} \mathrm{O}$-Moderated ${ }^{252} \mathrm{Cf}$ Calibration Facility," Health Phys, 1984, 46:97-106.

16. Schwartz, R. B., Eisenhauer, C. M. and Grundl, J. A., Experimental Verification of the Neutron Spectrum from the NBS $\mathrm{D}_{2} \mathrm{O}$-Moderated ${ }^{252} \mathrm{Cf}$ Source, NUREG/CR-3399, U.S. Nuclear Regulatory Commission, Washington, D.C., 1983.

17. Plato, P., and Hudson, G., Performance Testing of Personnel Dosimetry Services: Procedures Manual, NUREG/CR-1063, U.S. Nuclear Regulatory Commission, Washington, D.C., 1980.

18. McDonald, J. C., Griffith, R. V., Plato, P., and Miklos, J., Measurements of Gamma-Ray Dose From a Moderated ${ }^{252} C f$ Source, NUREG/CR-2975, PNL-4590, Pacific Northwest Laboratory, Richland, Washington, 1983.

19. U.S. National Bureau of Standards (NBS), Experimental Statistics, NBS Handbook 91, U.S. Government Printing Office, Washington, D.C., 1963.

20. U.S. Department of Energy, Department of Energy Laboratory Accreditation Program (DOELAP) for Personnel Dosimetry, DOE Order 5480 Series, U.S. Department of Energy, Washington, D.C.

21. Griffith, R. V., Hankins, D. E., Gammage, R. B., Tommasino, L., and Wheeler, R. V., "Recent Developments in Personnel Neutron Dosimeters - A Review," Health Phys, 1979, 36:235-260.

22. Currie, L. A. "Limits for Qualitative Detection and Quantitative Determination," Analytical Chemistry, 1968, 40:586-593. 


\section{APPENDIX A}

CHOICE OF REFERENCE CALIBRATION SOURCES 


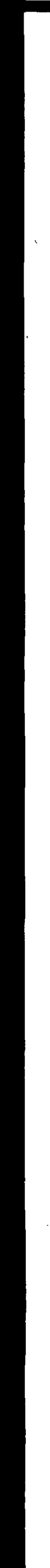




\section{APPENDIX A}

\section{CHOICE OF REFERENCE CALIBRATION SOURCES}

Comparisons of occupational exposures reported for various DOE sites are made more difficult by the absence of standard calibration techniques and the use of many dosimeter designs. The establishment of reference calibration techniques will help quantify the effects of differing dosimeter designs and differing occupational environments. The choice of reference sources was based on an intercomparison of dosimeter system performances for DOE laboratories $A-1$ and the American National Standards Institute's Criteria for Testing Personnel Dosimetry Performance, ANSI N13.11. A-2 Eleven DOE laboratories participated in the intercomparison to better define present differences and help develop improved techniques.

The intercomparison of dosimetry system performances was also used to evaluate ANSI N13.11 for use by DOE facilities. It was found that: 1) the number of test categories was incomplete; 2) the performance criteria specified did not achieve the goal of the tests as well as other algorithms; 3) the beta-particle category was not sufficiently specified; and 4) the choice of the photon conversion factors was arbitrary. The choice of reference sources was made to be as consistent with ANSI N13.11 as was practical.

\section{A.1 Calibration Categories}

The filtered $x$-ray beams chosen for Table 1 (main text) are National Bureau of Standards (NBS) techniques. ${ }^{A-3}$ The M30 (20-keV) and S60 (36-keV) techniques represent the photon energy region of maximum response for most dosimetry systems. They represent a conservative worst-case test for low-energy photons. The M150 (70-keV) and $\mathrm{H} 150(120-\mathrm{keV})$ techniques are included to extend the test energies above those influenced by the photoelectric effect. The response of dosimetry systems is similar to that of tissue from approximately $200 \mathrm{keV}$ to $2 \mathrm{MeV}$ because of the dominance of the Compton interaction. Tests at these energies are represented by the high-energy photon category. Nearly monoenergetic $x$-ray sources at 15 to $20 \mathrm{keV}$ and 55 to $65 \mathrm{keV}$ and the ${ }^{241} \mathrm{Am}$ (59-keV) source were included specifically for facilities using plutonium.

Adequate performance for the ${ }^{90} \mathrm{Sr} /{ }^{90} \mathrm{Y}$ beta source does not imply adequate performance for all beta-particle energies. The ${ }^{90} \mathrm{Sr} /{ }^{90} \mathrm{Y}$ beta particles are sufficiently energetic to penetrate the popular, thick $\left(235-\mathrm{mg} / \mathrm{cm}^{2}\right) \mathrm{LiF}$ thermoluminescent (TL) dosimeter chip. This penetration results in a response for ${ }^{90} \mathrm{Sr} /{ }^{90} \mathrm{Y}$ similar to the response for ${ }^{137} \mathrm{Cs}$ for some dosimeters that are nearly insensitive to low-energy beta particles. Inclusion of the ${ }^{204} \mathrm{~T}$ l source (0.76-MeV maximum energy) requires that some attention be given to the lower energies. Reference sources with energies lower than that provided by the ${ }^{204} \mathrm{Tl}$ source may be included following improvement in dosimeter technology. The ${ }^{204} \mathrm{Tl}$ source was chosen because of its ease of use and single beta spectrum.

A uranium slab source was added for occupational environments containing uranium and because of the popularity of this source type for dosimeter calibrations. Because source construction details may change dose rates slightly, extrapolation chamber measurements were specified for the calibration at $7 \mathrm{mg} / \mathrm{cm}^{2}$ and the depth-dose determination at $100 \mathrm{mg} / \mathrm{cm}^{2}$. Source construction and geometry effects are constrained by the depthdose specification, which was calculated using measurements reported in the literature, $A-4, A-5$ and which were subsequently checked by direct measurement. These measurements indicate that the depth-dose specification can be met for slab sources with protective coatings in the range of $3 \mathrm{mg} / \mathrm{cm}^{2}$ to $7 \mathrm{mg} / \mathrm{cm}^{2}$.

The use of dosimeters far from a uranium source may result in inaccurate readings compared to the uranium slab calibration. The slab geometry provides a less-penetrating depth-dose distribution than the point source geometry. Proper use of the source calibration can be determined using measurements performed in the occupational environments.

The response ratio of $\mathrm{DOE}$ albedo neutron dosimeters for moderated and unmoderated ${ }^{252} \mathrm{Cf}$ irradiations varies from approximately 6 to 20 . A-1 Because the variations are so large, both sources were chosen for use as reference sources. For the performance evaluation, the type of neutron source is provided before the dose equivalents are reported. The moderated ${ }^{252} \mathrm{Cf}$ source was chosen to be consistent with ANSI N13.11. Unmoderated ${ }^{252} \mathrm{Cf}$ irradiations can easily be performed as a variation of the moderated ${ }^{252} \mathrm{Cf}$ irradiations. More 
stringent neutron tests may be included following improvements in neutron dosimeter technology.

\section{A.2 Additional Specifications for Beta Calibrations}

Beta calibrations are affected by source geometry, source filtration, dosimeter irradiation technique, beam calibration technique, and environmental conditions. The ANSI N13.11 standard specifies inherent source filtration, phantom size, and source-to-phantom distance for ${ }^{90} \mathrm{Sr} /$ ${ }^{90} \mathrm{Y}$ irradiations but does not adequately address other parameters. Considerable variability in dosimeter response per unit delivered dose has been observed among ${ }^{90} \mathrm{Sr} /{ }^{90} \mathrm{Y}$ sources set up to ANSI N13.11 specifications. Additional constraints are necessary to standardize beta calibration techniques.

This standard specifies that beta irradiations be standardized according to depth-dose characteristics and source energy criteria in the international standard ISO $6980 . \mathrm{A}-6$ The specifications for ${ }^{90} \mathrm{Sr} /{ }^{90} \mathrm{Y}$ irradiation are related to the mean energy of the source (100-mg/ $\mathrm{cm}^{2}$ specification) and Bremsstrahlung production (1000-mg $/ \mathrm{cm}^{2}$ specification). For ${ }^{204} \mathrm{Tl}$ irradiations, only a specification related to mean energy is given (20-mg/ $\mathrm{cm}^{2}$ specification). The depth-dose specifications are intended to take precedence over the source filtration specifications. The intention is to allow the use of source geometries specified in ISO 6980 while maintaining irradiation consistency between laboratories. The depth-dose specification for the slab uranium exposures was added to help control variations in source manufacture and geometry.

\section{A.3 Factors for Converting Exposure to Dose Equivalent for Photons}

The exposure-to-dose-equivalent conversion factors for low-energy photons $\left(C_{x}\right.$ factors) listed in ANSI N13.11 were derived by Dimbylow and Francis for the four-element ICRU sphere using
Monte Carlo calculations. A-7 For the dosimeter performance tests, the dosimeters are mounted on a slab phantom of methylmethacrylate. Personnel dosimeters are designed to monitor for dose to the tissue of the body on which they are mounted. However, the performance tests require that they monitor for dose to the ICRU sphere while mounted on a slab phantom. This results in the miscalibration of even ideal personnel dosimeters.

The choice of the phantom shape for the specification of $C_{x}$ factors is not arbitrary, as has been argued. $A-8$ The size and shape of the phantom is important for monitoring low-energy photons because radiation is scattered back to the surface. Backscatter can contribute an additional $40 \%$ to $50 \%$ to the dose at the surface for photon energies between 60 and $100 \mathrm{keV} . \mathrm{A}-9$ The dosimeter ideally would be able to properly record the level of backscattered radiation and, thus, approximately compensate for fluctuations dependent on the size of the wearer.

The contribution due to backscattered radiation is different for the slab and spherical phantoms. Nelson and Chilton used Monte Carlo calculations to derive the $C_{x}$ factors for the slab geometry with the ICRU four-element composition. $A=10$ Their results agreed closely with the calculations of Dimbylow and Francis (spherical geometry) below $50 \mathrm{keV}$, but were $20 \%$ higher between 80 and $100 \mathrm{keV}$. This difference accounts for the major discrepancy between the spherical-geometry $C_{x}$ factors specified in ANSI N13.11 and the available measurements using slab geometry by Yoder et al. A-11 Nelson and Chilton also performed calculations for the tissue-equivalent plastic used by Yoder et al. for direct measurements of $C_{x}$ factors using the slab geometry. The significant difference between the calculations for the Yoder plastic and the measurements was at energies below $20 \mathrm{keV}$. Nelson and Chilton attributed this difference to a higher-energy contamination in the k-fluorescence spectra used by Yoder et al.

Because of the use of slab phantoms for the reference calibrations, conversion factors for the slab geometry are used. The best available data are by Yoder et al. and are listed in Table 2 of the main text. 


\section{REFERENCES}

A-1. Roberson, P. L., Holbrook, K. L., Yoder, R. C., Fox, R. A., Hadly, R. T., Hogan, B. T., and Hooker, C. D., Performance Comparisons of Selected Personnel Dosimetry Systems in Use at Department of Energy Facilities, PNL-3983, 'Pacific Northwest Laboratory, Richland, Washington, 1983.

A-2. American National Standards Institute (ANSI), American National Standard, Criteria for Testing Personnel Dosimetry Performance, ANSI N13.11-1983, New York, New York, 1983.

A-3. U.S. National Bureau of Standards (NBS), NBS Calibration Services Users Guide, NBS Special Publication 250, U.S. Government Printing Office, Washington, D.C., 1986.

A-4. Plato, P., "Absorbed Dose Rate Produced by Natural Uranium as a Function of Depth in Tissue," Int. J. App. Rad. Iso., 1979, 30:109-113.

A-5. Coleman, R. L., Hudson, C. G., and Plato, P. A., "Depth-Dose Curves for ${ }^{90} \mathrm{Sr}$ and Natural and Depleted Uranium in Mylar," Health Phys., 1983, 44(4):395-402.

A-6. International Organization for Standardization (ISO), Reference Beta Radiations for Calibrating Dosemeters and Doseratemeters and for Determining Their Response as a Function of Beta Radiation Energy, ISO 6980-1984, UDC 535-34:539.165:53.089.6., Geneva, Switzerland, 1984.

A-7. Dimbylow, P. J. and Francis, T. M., A Calculation of the Photon Depth-Dose Distributions in the ICRU Sphere for a Broad Parallel Beam, A Point Source and an Isotropic Field, NRPB 92, National Radiological Protection Board, Harwell, England, 1979.

A-8. Ehrlich, M., "Choice of Conversion Factors to the Shallow and Deep Dose Equivalent for Use in a U.S. Personnel Dosimetry Performance Testing Programme," Radiation Protection Dosimetry 1, 1982, (4):271-275.

A-9. Johns, H. E. and Cunningham, J. R., The Physics of Radiology. Charles C. Thomas Publishing, Springfield, Illinois, 1978, p. 322.

A-10. Nelson, R. F. and Chilton, A. B., "Depth Doses in Slab Phantom for Low Energy Monoenergetic Photons," Radiation Protection Dosimetry, 1982, 1(4):285-289.

A-11. Yoder, R. C., Bartlett, W: T, Courteny, J. W., Hooker, C. D., Holland, J. A., and Hogan, B. T., Confirmation of Conversion Factors Relating Exposure and Dose-Equivalent Index Presented in ANSI N13.11, NUREG/CR-1057, PNL-3219, Pacific Northwest Laboratory, Richland; Washington, 1979. 


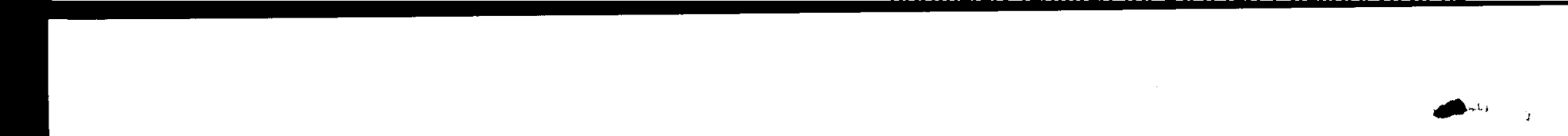




\section{APPENDIX B}

\section{DERIVATION OF PERFORMANCE CRITERIA}

The specifications of performance criteria were based on achievable standards consistent with the goals of health protection. The criteria were chosen to be both economically and technologically achievable based on the data collected during the intercomparison of dosimeter system performance for DOE laboratories. ${ }^{\mathrm{B}-1}$ A direct relationship between the performance criterion and the response of each dosimeter was maintained by expressing the criterion as a confidence limit rather than a calibration bias limit only. The confidence limit concept was also used in ANSI N13.111983. B-2 The goal was to develop a statistic for which there would be a specified confidence that the dosimeter readings would be within a specified interval.

For a large number of dosimeter readings obeying a normal distribution, there is a confidence level, $\beta$, for which the readings are within the interval

$$
M-Z_{\alpha} \sigma \text { to } M+Z_{\alpha} \sigma
$$

where $M$ is the mean; $\sigma$ is the (one sigma) standard deviation of the total population; and $\mathrm{Z}_{\alpha}$ is the standard normal variable for $\alpha=1 / 2(\beta+1)$. The entire interval may be required to be within a specified tolerance of a conventionally true value (CTV) by stating:

$\mathrm{M}+\mathrm{Z}_{\alpha} \sigma \leq \operatorname{CTV}(1+\mathrm{L})$

and

$\mathrm{M}-\mathrm{Z}_{\alpha} \sigma \geq \operatorname{CTV}(1-\mathrm{L})$

or

$\frac{|\mathrm{M}-\mathrm{CTV}|}{\mathrm{CTV}}+\frac{\mathrm{Z}_{\alpha} \sigma}{\mathrm{CTV}} \leq \mathrm{L}$

where $\mathrm{L}$ is the fractional tolerance interval.

For a performance test using $n$ dosimeters, the bias (B) and the standard deviation (S) of the performance indices are estimates of (M - CTV)/CTV and $\sigma / \mathrm{CTV}$. Then the test statistic becomes
$\left|B_{n}\right|+t_{\alpha, \nu} S_{n, \nu} \leq L$

where $\nu=\mathrm{n}-1$ represents the number of degrees of freedom and the ' $t$ ' statistic is used as an approximation of the standard normal variable due to the finite number of dosimeters used for the test.

The reasonably achievable test statistic chosen for the performance criterion was

$|\mathrm{B}|+\mathrm{S} \leq 0.30$

This statistic can be interpreted in several ways. If $\mathrm{t}_{\alpha, \nu}=1$ for $\mathrm{n}=15$ dosimeters, then there would be approximately $70 \%$ confidence $(\beta=0.66$, $\alpha=0.83$ for $n=15$ ) that a dosimeter response would be within $30 \%$ of a conventionally true value. However, if a worker used four dosimeters per year and received approximately equal doses on each, then there would approximately $95 \%$ confidence $(\beta=0.93, \alpha=0.97$ for $\mathrm{n}=15$ ) that the annual reported dose equivalent would be within $30 \%$ of a conventionally true value.

Variations of the test statistic derivation are possible. Higher levels of statistical confidence that a test sample is representative of the true population can be obtained using tolerance statistics. ${ }^{\mathrm{B}-3}$ An interval can be constructed to cover at least a specified percent of all dosimeter readings in the total population with a desired probability. For example, for a $95 \%$ probability that $95 \%$ of the averages of four dosimeter readings are within tolerance (assuming uniform occupational exposures and a quarterly exchange rate), the test statistic becomes:

$|\mathrm{B}|+1.45 \mathrm{~S} \leq 0.30$

for 15 sample readings. However, there is also the probability that a system that meets the $30 \%$ criteria exceeds the test statistic. For $95 \%$ probability that systems meeting requirements also meet the test statistic, the tolerance value $(0.30)$ would have to be increased. Both approaches converge to the adopted test statistic as the number of sample dosimeters approaches infinity.

The relationship of the adopted test statistic (Equation B-4) to recommendations of the NCRP, ICRU and ICRP are given below. 


\section{Recommendations to NCRP 57B-4}

The NCRP recommends several values of precision and accuracy depending on the circumstance. The recommended precision is $\pm 10 \%$ which allows comparison of reported values between individuals and over long periods of time. For reported values near the maximum permissible dose (MPD), an accuracy of $\pm 30 \%$ is recommended. For reported values less than $1 / 4$ of the MPD, an accuracy of a factor of 2 is acceptable. At higher doses encountered during emergency procedures or accidents, an accuracy of better than $\pm 20 \%$ is recommended.

The precision of the reported values approximately corresponds to the ' $S$ ' value. While the test statistic does not require an $S$ of 0.10 or less, there is an implied constraint on $S$ of about 0.12 to 0.15 . Larger values of $S$ do not allow sufficient latitude for a minimal uncertainty in the bias, especially for multipurpose dosimeters which require some latitude in the bias to cover response variation as a function of radiation type and energy. The spirit of the recommendation for precision is accommodated.

The recommended accuracy near the MPD of $30 \%$ is implied to be used annually, since the MPD is applied annually. If a facility uses quarterly dosimeter exchanges, dosimeters receiving approximately equal doses per quarter would meet the $30 \%$ recommendations with approximately $95 \%$ confidence. The reported dose equivalent for a worker receiving all of the annual dose on one dosimeter would have an approximately $70 \%$ confidence of meeting the recommendation.

A test statistic variable in the magnitude of the delivered dose was contained in the early drafts of ANSI N13.11. The University of Michigan test concluded, and the DOE study concurred, that the split in the test statistic was unnecessary at current state of the art and was detrimental to the conduct of the test. Principally, a significantly larger number of dosimeters would be required to perform a variable-criteria test compared to a single-criteria test to achieve the same level of confidence in the results. Therefore, the allowance for a greater inaccuracy at lower doses was not inciuded in the test criteria.

The test statistic does not meet the $\pm 20 \% \mathrm{rc}$ ommendation on the accuracy at high doses. High doses are typically received by only one dosimeter, thus there would be $70 \%$ confidence that the reported dose is within $30 \%$.

\section{Recommendations in ICRU 20B-5}

The ICRU recommends that an accuracy of $\pm 30 \%$ be achieved when the maximum dose equivalent is comparable to the maximum permissible dose. At a level of 0.1 of the maximum permissible dose, a maximum allowable uncertainty of a factor of three is suggested. At doses much greater than the maximum permissible dose, the ICRU recommends that the accuracy be increased, possibly with special effort applied postexposure.

The accuracy recommended by the ICRU is similar to that quoted by the NCRP at radiation protection levels. At high doses, the ICRU encourages the use of special efforts to improve the dose estimate for each individual worker. The adopted test criteria is in approximate agreement with these recommendations. However, there is no test requirement to demonstrate the ability to improve the accuracy after the exposure.

\section{Recommendations in ICRP $35^{\mathrm{B}-6}$}

The ICRP recommends that the uncertainty in the annual reported dose equivalent be reduced as far as is reasonably achievable. It further recommends minimum levels of accuracy of a factor of 1.5 at the $95 \%$ confidence limit when the dose equivalent is on the same order as the annual maximum permissible dose, or within a factor of two at the $95 \%$ confidence level when the annual reported dose is less than 1 rem. Explicitly stated is that these accuracy limits include variations in dosimeter sensitivity, with incident energy and direction of incidence, and in dosimeter construction, readout, and calibration.

The first recommendation is met: the criteria was designed to be as low as is reasonably achievable. The recommended minimum levels of accuracy near the maximum permissible dose imply a test statistic of

$|\mathrm{B}|+2 \mathrm{~S} \leq 0.50$ for B positive

and

$|B|+2 S \leq \mathbf{0 . 3 3}$ for B negative.

The asymmetric criterion is due to the specification of a factor rather than a percent of the conventionally true value. This statistic implies an upper limit of $S$ of 0.25 , which is approximately achieved by 
the adopted statistic $\left(S_{\max }=0.30\right)$. The adopted criteria approximately corresponds to recommendations of the ICRP for S values near 0.20. However, the allowed inaccuracy of the bias for small $S$ values is (nearly) as great as $50 \%$. This allows too much inaccuracy in the calibration methods and dosimeter design, and is above the currently achievable level. Note that this approach does not require the use of quarterly dosimeter exchanges with the accompanying assumption of approximately equal doses received each quarter.

A source of inaccuracy included by the ICRP, but not included by the adopted test criteria is that due to direction of radiation incidence. The collection of angular response data is required by the DOE standard with no criteria on the performance. The application of the adopted test statistic may be alternatively viewed as allowing a confidence interval up to 0.2 for the inaccuracy in the angular response. The recommendations of the ICRP can be taken into account during the development and subsequent review of a test criteria for angular response.

The recommendations at the lower dose equivalent levels were not used for the same reason as was stated above for the NCRP recommendations.

\section{Summary of Relationship to NCRP/ICRU/ICRP Recommendations ${ }^{B-4}$ through B-6}

The adopted performance criteria were chosen to be as low as was reasonably achievable. The criterion is consistent with the recommendations of the NCRP, ${ }^{B-4}$ ICRU, ${ }^{\mathrm{B}-5}$ and ICRP ${ }^{\mathrm{B}-6}$ with the following caveats:

- To meet the NCRP and ICRU recommendations of $30 \%$ for the accuracy, and do it with $\mathbf{9 5 \%}$ confidence, at least four dosimeters receiving equal doses must be used. This may be approximately correct for the majority of workers, but is not adequate for all.

- The recommendations by the ICRP are approximately met for each dosimeter, and thus for each worker, except that the uncertainty due to angular response is neglected in the test criteria. The adopted test criteria are approximately equivalent to reserving up to $20 \%$ for additional (positive) bias due to angular response variations.
- The NCRP recommended accuracy in the high dose region is greater than is specified by the test criteria $(20 \%$ NCRP versus $30 \%$ test criteria). The ICRU and ICRP favor special effort to increase accuracy on a case-by-case basis.

- Inaccuracies resulting from field use under partially unknown conditions (e.g., position of dosimeter relative to the source distribution and body of wearer) are neglected in the test criteria.

\section{Performance Test Uncertainty}

The implementation of the test statistic as given in Equation (B.4) may require large numbers of dosimeters to measure $|\mathrm{B}|$ and $S$ with sufficient precision. Assuming that the dosimeter readings are normally distributed about a single mean, for $95 \%$ of the readings the magnitude of the bias is bounded by:

$$
|\mathrm{B}| \leq \frac{|\mathrm{M}-\mathrm{CTV}|}{\mathrm{CTV}}+\frac{\mathrm{Z}_{0.975}}{\sqrt{\mathrm{n}}} \frac{\sigma}{\mathrm{CTV}}
$$

For $95 \%$ of the samples the standard deviation is approximately bounded by:

$S \leq\left(\frac{\chi_{0.95}^{2}}{n-1}\right)^{1 / 2} \cdot \frac{\sigma}{C T V}$

using a $\chi^{2}$ distribution with ( $\left.\mathrm{n}-1\right)$ degrees of freedom. Because the uncertainties in $B$ and $S$ are independent for normally distributed data, a close approximation to the interval containing $95 \%$ of the parent population is:

$$
\begin{aligned}
{[|B|+S]_{\max }=\frac{|M-C T V|}{C T V}+\frac{\sigma}{C T V} } \\
+\left\{\left(\frac{Z_{0.975}}{n}\right)^{2}\right. \\
\left.+\left[\left(\frac{x_{0.95}^{2}}{n-1}\right)^{1 / 2}-1\right]^{2}\right\}^{1 / 2} \frac{\sigma}{C T V}
\end{aligned}
$$

The term in brackets on the right-hand side is the amount by which a system that meets the goals for accuracy could fail the test statistic due to a statistical fluctuation of a measurement. This term can be 
Table B-1. Statistical uncertainty term

\begin{tabular}{|c|c|c|}
\hline$\sigma / \mathrm{CTV}$ & $\begin{array}{l}\text { Number of } \\
\text { Dosimeters }\end{array}$ & $\begin{array}{c}\text { Approximate Value of } \\
\text { Uncertainty Term }\end{array}$ \\
\hline 0.08 & 15 & 0.05 \\
\hline 0.17 & $\begin{array}{l}15 \\
30 \\
60\end{array}$ & $\begin{array}{l}0.10 \\
0.17 \\
0.05\end{array}$ \\
\hline 0.24 & $\begin{array}{r}15 \\
30 \\
60 \\
120\end{array}$ & $\begin{array}{l}0.14 \\
0.10 \\
0.07 \\
0.05\end{array}$ \\
\hline
\end{tabular}

reduced by increasing the number of dosimeters per test.' Table B.1 lists the approximate values of the statistical terms as a function of $\sigma$ and the number of dosimeters used per test. For an uncertainty of $5 \%, 15,60$, and 120 dosimeters are required for standard deviations of $0.08,0.17$, and 0.24 , respectively. Similar requirements for the number of sam: ple dosimeters can be derived using tolerance statistics for $95 \%$ probability that $70 \%$ of a parent population with $|\mathrm{B}|+\mathrm{S}=0.25$ is within tolerance. 


\section{REFERENCES}

B-1. Roberson, P. L., Holbrook, K. L., Yoder, R. C., Fox, R. A., Hadly, R. T., Hogan B. T., and Hooker, C. D., Performance Comparisons of Selected Personnel Dosimetry Systems in Use at Department of Energy Facilities, PNL-3983, Pacific Northwest Laboratory, Richland, Washington, 1983.

B-2. American National Standards Institute (ANSI), American National Standard, Criteria for Testing Personnel Dosimetry Performánce, ANSI N13.11-1983, New York, New York, 1983.

B-3. National Council on Radiation Protection and Measurements (NCRP), A Handbook of Radioactivity Measurements Procedures, NCRP Report No. 58, Washington, D.C., 1978.

B-4. National Council on Radiation Protection and Measurements (NCRP), Instrumentation and Monitoring Methods for Radiation Protection, NCRP Report No. 57, Washington, D.C., 1978.

B-5. International Commission on Radiation Units and Measurements (ICRU), Radiation Protection Instrumentation and Its Application, ICRU Report No. 20, Washington, D.C., 1971.

B-6. International Commission on Radiological Protection (ICRP), General Principles of Monitoring for Radiation Protection of Workers, ICRP 35, Pergamon Press, Oxford, United Kingdom, 1982. 


\section{DISTRIBUTION LIST}

Technical Information Center

UC-41 Distribution

R. W. Barber, Director

Nuclear Reactor and Facility

Safety Division, U.S. Department

of Energy, Washington, DC

N. Goldenberg, Acting Director

Quality Assurance, U.S.

Department of Energy,

Washington, DC

B. L. Murphy, Health Physics, U.S. Department of Energy,

Washington, DC

D. F. Bunch, Acting

Deputy Asst. Secretary for

Safety, Health, and

Quality Assurance,

U.S. Department of

Energy, Washington, DC

R. J. Stern, Director

Office of Environmental

Guidance, U.S. Department of

Energy, Washington, DC

E. J. Vallario, Acting Director

Radiological Controls Division,

Office of Nuclear Safety,

U.S. Department of Energy,

Washington, DC (10)

M. Marelli, Health Physics,

U.S. Department of

Energy, Washington, DC

M. Walker, Assistant Secretary

for Environment, Safety and

Health, U.S. Department of

Energy, Washington, DC
D. L. Bray, U.S. Department of Energy, Chicago Operations Office, 9800 S. Cass Ave., Argonne, IL

Paul Neeson, U.S. Department of Energy, Chicago Operations Office, 9800 S. Cass Ave., Argonne, IL

Juris Balodis, U.S. Department of. Energy, Princeton Area Office, P.O. Box 102, Princeton, NJ

L. V. Coulson, Head Safety Section, Fermi National Accelerator Laboratory, P.O. Box 500, Batavia, IL

C. B. Meinhold, Head

Safety \& Environmental

Protection Division, Brookhaven National Laboratory, Upton, NY

Joseph Stencil, Princeton Plasma Physics Laboratory, P.O. Box 451, Princeton, NJ

John Gulbin, U.S. Department of Energy, Environmental Measurements Lab., 376 Hudson St., New York, NY

M. D. Voss, Ames Lab, Iowa State University, Ames, IO

F. X. Masse, Radiation Protection Office, Massachusetts Institute of Technology, Bates Linear Accelerator, P.O. Box 95, Middleton, MA 
R. L. Miller, Acting Director Environmental Safety \& Health Division, U.S. Department of Energy, Albuquerque Operations Office,

P.O. Box 5400, Albuquerque, NM (15)

Carleton D. Bingham, Director U.S. Department of Energy, Chicago Operations Office, New Brunswick Laboratory, 9800 South Cass Avenue, Argonne, IL

Ronald D. Duncan, Solar Energy

Research Institute, 1617 Cole

Blvd., Golden, CO

S. R. Elliott, U.S. Department of Energy, Nevada Operations Office, P.O. Box 14100, Las Vegas, NV

J. D. Moroney III, U.S. Department of Energy, Nevada Operations Office, P.O. Box 14100, Las Vegas, NV

Billy Smith, Reynolds Electrical \& Engineering Co., Inc., Environmental Sciences Division, P.O. Box 14400, Las Vegas, NV

Arden Bicker, Manager Environmental Sciences Dept., Nevada Test Site, Mercury, NV

T. M. Jelinek, Chief Health Protection Branch, U.S. Department of Energy, Oak Ridge Operations Office, P.O. Box E, Oak Ridge, TN

D. B. Howard, U.S. Department of Energy, Oak Ridge Operations Office, P.O. Box E, Oak Ridge, TN
Harley Toy, Battelle Memorial

Institute, Columbus, $\mathrm{OH}$

\section{R. C. Baker, Head}

Environmental Control Department, Paducah Gaseous Diffusion Plant, Martin Marietta Energy Systems, Inc., P.O. Box 1410, Paducah, KY

W. T. Mee, Superintendent Radiation Safety Department Y-12 Plant, Martin Marietta Energy Systems, Inc., P.O. Box Y, Oak Ridge, TN

B. G. Roach, Head Health and Safety Office, Oak Ridge Associated Universities, P.O. Box 117, Oak Ridge, TN

Ed Wagner, Head Industrial Hygiene and Health Physics Department, Goodyear Atomic Corporation, P.O. Box 628, Piketon, OH

W. C. Borden, Manager Safety and Licensing Group, FUSRAP Project, Bechtel National, Inc., P.O. Box 350, Oak Ridge, TN

Howard Christiansen, Manager Environmental and Radiological Safety, Westinghouse Materials Company of Ohio, P.O. Box 398704, Cincinnati, $\mathrm{OH}$

F. G. Van Loocke, Health, Safety and Security, RMI, Extrusion Plant, P.O. Box 579, Ashtabula, $\mathrm{OH}$

Werner F. Furth, Director Environmental Safety and Health, Martin Marietta Energy Systems, Inc., P.O. Box X, Oak Ridge, TN 
David Duncan, Head

Industrial Hygiene and Health Physics

Department, Oak Ridge Gaseous

Diffusion Plant, Martin Marietta

Energy Systems, Inc.,

P.O. Box P, Oak Ridge, TN

Dennis C. Parzyck, Environmental and Occupational Safety Division, Oak Ridge National Laboratory, Martin Marietta Energy Systems, Inc., P.O. Box X, Oak Ridge, TN

J. M. Selby, Pacific Northwest Laboratory, P.O. Box 999,

Richland, WA (5)

J. J. Fix, Pacific Northwest

Laboratory, P.O. Box 999, Richland, WA

P. L. Roberson, Pacific Northwest Laboratory, P.O. Box 999, Richland, WA (5)

C. D. Hooker, Pacific Northwest Laboratory, P.O. Box 999, Richland, WA

L. G. Faust, Pacific Northwest Laboratory, P.O. Box 999, Richland, WA

J. T. Davis, U.S. Department of Energy, San Francisco Operations Office, 1333 Broadway, Oakland, CA

Phil Hill, U.S. Department of Energy, San Francisco Operations Office, 1333 Broadway, Oakland, CA

T. Jordan Powell, Lawrence Livermore National Laboratory, L380 Building 255, P.O. Box 808, Livermore, CA

Nathanial A. Greenhouse, Building B75B, Lawrence Berkeley Laboratory, Berkeley, CA
R. E. Gerton, U.S. Department of Energy, Richland Operations Office, $825 \mathrm{Jadwin}$ Avenue, P.O. Box 550, Richland, WA

Eric Erickson, U.S. Department of Energy, Richland Operations Office, 825 Jadwin Avenue, P.O. Box 550, Richland, WA

Norris D. Johnson, E. I. DuPont deNemours, Savannah River Plant, Aiken, SC

T. L. Collins, Manager Knolls Atomic Power Laboratory, U.S. Department of Energy, P.O. Box 1072, Schenectady, NY

A. C. Davis, Manager Bettis Àtomic Power Laboratory, Westinghouse Electric Corporation, P.O. Box 79, West Mifflin, PA

C. K. Gaddis, Manager Pittsburgh Naval Reactors Office, P.O. Box 109, West Mifflin, PA

A. Richardson, EPA Office of Radiation Protection, Criteria \& Standards Division, AW-460, 401 M Street, SW, Washington, DC

J. T. Lewis, Center for Dev. \& Radiol. Health, Office of Health Physics, HFZ-60, Rm. Chap. 332, 5600 Fishers Lane, Rockville, MD

J. C. Villforth, Director FDA Bureau of Radiological Health, Rockville, MD

R. Colle, National Bureau of Standards, Gaithersburg, MD

E. H. Eisenhower, Office of Radiation Measurement, National Bureau of Standards, Gaithersburg, MD 
Don Busick, Stanford Linear Accelerator, P.O. Box 4349, Stanford, CA

Bob Tuttle, Rockwell International, Rocketdyne Division, 6633 Canoga Ave., Canoga Park, CA

D. N. Bridges, U.S. Department of Energy, Savannah River Operations Office, P.O. Box A, Aiken, SC

Paul Matthews, U.S. Department of Energy, Savannah River Operations Office, P.O. Box A, Aiken, SC

\section{R. E. Alexander, Chief} Radiation Risk Assessments and Management Branch, Office of Nuclear Regulatory Research, U.S. Nuclear Regulatory Commission, Washington, DC

\section{A. Brodsky, U.S. Nuclear} Regulatory Commission, Wilste Bldg., MS-1130 SS, 7515 Eastern Ave., Silver Spring, MD

L. K. Cohen, Office of Inspection \& Enforcement, U.S. Nuclear Regulatory Commission, Washington, DC

\section{J. Cunningham, Operating} Reactor Programs Branch, Division of Inspection Programs, U.S. Nuclear Regulatory Commission, Washington, DC

M. V. Federline, Office of Executive Director for Operation, U.S. Nuclear Regulatory Commission, Washington, DC

K. R. Goller, Division of Rad. Prog. \& Earth Sciences, U.S. Nuclear Regulatory Commission, MS-1130 SS, Washington, DC
R. Loevinger, National Bureau of Standards, Gaithersburg, MD

G. Ehrlich, National Bureau of Standards, Gaithersburg, MD

R. B. Schwartz, National Bureau of Standards, Building 235, Gaithersburg, MD

E. H. Doleck, Building 201, Argonne National Laboratory, 9700 S. Cass Avenue,

Argonne, IL

L. F. Phillips, Building 535A, Brookhaven National Laboratory, Upton, NY

D. J. Thompson, Sandia National Laboratories, Organization 3313, P.O. Box 5800 , Albuquerque, NM

D. G. Vasilik, Los Alamos National Laboratory, P.O. Box 1663,

Los Alamos, NM

R. B. Falk, Rockwell International, P.O. Box 464, Golden, $\mathrm{CO}$

G. W. Campbell, Rockwell International, P.O. Box 464, Golden, CO

J. R. Cortez, Los Alamos National Laboratory, P.O. Box 1663, Los Alamos, NM 
R. E. Minogue, Director Office of Nuclear Regulatory Research, U.S. Nuclear Regulatory Commission, Washington, DC

R. B. Neel, U.S. Nuclear Regulatory Commission, Wilste Bldg., MS-1130 SS, 7515 Eastern Ave., Silvèr Spring, MD

L. C. Rouse, Chief

Advanced Fuel and Spent Fuel Licensing Branch, Division of Fuel Cycle \& Material Safety, U.S. Nuclear Regulatory Commission, Washington, DC

J. M. Aldrich, HS\&E, Building 123, Rockwell International, P.O. Box 464, Golden, CO

R. E. Wood, Acting Asst. Mgr. Environmental, Safety \& Health Programs U.S. Department of Energy Idaho Operations Office Idaho Falls, ID

G. C. Bowman

U.S. Department of Energy

Idaho Operations Office

Idaho Falls, ID

T. F. Gesell, Chief

Dosimetry Branch

Radiological and Environmental

Sciences Laboratory

U.S. Department of Energy

Idaho Falls, ID (50)

R. D. Carlson

Dosimetry Branch

Radiological and Environmental

Sciences Laboratory

U.S. Department of Energy

Idaho Falls, ID
J. H. Elliot, Lawrence Livermore National Laboratory,

P.O. Box 808, Livermore, CA

C. L. Graham, Lawrence Livermore National Laboratory,

P.O. Box 808,

Livermore, CA

R. M. Hall, E. I. DuPont

deNemours \& Co.,

Savannah River Plant, Aiken, SC

R. Lawrence, West Valley

Nuclear Services

P.O. Box 191

Rock Springs, Rd., West Valley, NY

W. Nees

United Nuclear Corp.

P.O. Box 14000

Grand Junction, CO

J. J. Volpe

Westinghouse Electric Corporation

P.O. Box 2068

Idaho Falls, ID

C. D. Sorensen

EG\&G Idaho, Inc.

P.O. Box 1625

Idaho Falls, ID

C. S. Abrams

Argonne National Laboratory

Idaho Site

P.O. Box 2528

Idaho Falls, ID 